\title{
Ultraviolet stress delays chromosome replication in light/dark synchronized cells of the marine cyanobacterium Prochlorococcus marinus PCC9511
}

\author{
Christian Kolowrat ${ }^{1,2}$, Frédéric Partensky ${ }^{1,2^{*}}$, Daniella Mella-Flores ${ }^{1,2}$, Gildas Le Corguillé ${ }^{1,3}$, Christophe Boutte ${ }^{1,2}$, \\ Nicolas Blot ${ }^{1,2,4}$, Morgane Ratin ${ }^{1,2}$, Martial Ferréol ${ }^{5}$, Xavier Lecomte ${ }^{1,2}$, Priscillia Gourvil ${ }^{1,2}$, Jean-François Lennon ${ }^{1}$, \\ David M Kehoe ${ }^{6}$, Laurence Garczarek ${ }^{1,2}$
}

\begin{abstract}
Background: The marine cyanobacterium Prochlorococcus is very abundant in warm, nutrient-poor oceanic areas. The upper mixed layer of oceans is populated by high light-adapted Prochlorococcus ecotypes, which despite their tiny genome $(\sim 1.7 \mathrm{Mb})$ seem to have developed efficient strategies to cope with stressful levels of photosynthetically active and ultraviolet (UV) radiation. At a molecular level, little is known yet about how such minimalist microorganisms manage to sustain high growth rates and avoid potentially detrimental, UV-induced mutations to their DNA. To address this question, we studied the cell cycle dynamics of $P$. marinus PCC9511 cells grown under high fluxes of visible light in the presence or absence of UV radiation. Near natural light-dark cycles of both light sources were obtained using a custom-designed illumination system (cyclostat). Expression patterns of key DNA synthesis and repair, cell division, and clock genes were analyzed in order to decipher molecular mechanisms of adaptation to UV radiation.
\end{abstract}

Results: The cell cycle of $P$. marinus PCC9511 was strongly synchronized by the day-night cycle. The most conspicuous response of cells to UV radiation was a delay in chromosome replication, with a peak of DNA synthesis shifted about $2 \mathrm{~h}$ into the dark period. This delay was seemingly linked to a strong downregulation of genes governing DNA replication (dnaA) and cell division ( $f t s Z$, sepF), whereas most genes involved in DNA repair (such as recA, phrA, uvrA, ruvC, umuC) were already activated under high visible light and their expression levels were only slightly affected by additional UV exposure.

Conclusions: Prochlorococcus cells modified the timing of the $S$ phase in response to UV exposure, therefore reducing the risk that mutations would occur during this particularly sensitive stage of the cell cycle. We identified several possible explanations for the observed timeshift. Among these, the sharp decrease in transcript levels of the dnaA gene, encoding the DNA replication initiator protein, is sufficient by itself to explain this response, since DNA synthesis starts only when the cellular concentration of DnaA reaches a critical threshold. However, the observed response likely results from a more complex combination of UV-altered biological processes.

\section{Background}

Since its discovery two decades ago [1], the marine cyanobacterial genus Prochlorococcus has rapidly become established as a model organism in microbial ecology [2-4]. As for other cyanobacteria with an obligate photoautotrophic lifestyle, Prochlorococcus has an absolute

\footnotetext{
*Correspondence: partensky@sb-roscoff.fr
'UPMC-Université Paris 06, Station Biologique, Place Georges Teissier, 29680

* Correspondence: partensky@sb-roscoff.fr
'UPMC-Université Paris 06, Station Biologique, Place Georges Teissier, 29680 Roscoff, France
}

(c) 2010 Kolowrat et al; licensee BioMed Central Ltd. This is an Open Access article distributed under the terms of the Creative Commons Attribution License (http://creativecommons.org/licenses/by/2.0), which permits unrestricted use, distribution, and reproduction in any medium, provided the original work is properly cited. light availability imposes a synchronization of its whole metabolism. Indeed, light/dark (L/D) entrained Prochlorococcus cells were shown to display a strong diurnal periodicity of many cellular functions, including cell cycle [6-8], pigment synthesis [9], carbon fixation [10], and amino acid uptake [11]. Synchronization primarily acts on gene expression, as evidenced first by studies focusing on individual cell cycle (e.g. $\operatorname{dnaA}, \mathrm{fts} Z$ ) and 
photosynthesis related genes (e.g. pcbA, psbA) [12,13], then more recently at the whole transcriptome level [14]. Under optimal growth conditions, generation times of Prochlorococcus populations are generally around $24 \mathrm{~h}$, though faster growth rates have sometimes been reported [8]. The DNA replication period is usually restricted to the late afternoon and dusk period and cytokinesis occurs during the night $[6,7,13]$.

Studying the interplay between energy source fluctuations (i.e. changes in light quantities and/or spectral composition) and cell cycle dynamics of Prochlorococcus is of special interest as it lays the foundation for designing reliable population growth models for this key organism, considered to be the most abundant free-living photosynthetic organism on Earth [15]. As early as 1995, Vaulot and coworkers [7] noticed that in field populations of Prochlorococcus, the timing of DNA replication varied with depth, with the initiation of DNA synthesis occurring about $3 \mathrm{~h}$ earlier below the thermocline than in the upper mixed layer. At that time, these authors interpreted this delay as a possible protective mechanism to prevent exposure of replicating DNA to the high midday irradiances and especially UV. Since then, a number of studies have shown that Prochlorococcus populations are in fact composed of several genetically distinct ecotypes adapted to different light niches in the water column [16-18]. The upper mixed layer is dominated by the so-called high light adapted (HL) ecotypes (HLI and HLII, also called eMED4 and eMIT9312, respectively), whereas low light adapted (LL) ecotypes (such as LLII and LLIV, also called eSS120 and eMIT9313, respectively) are restricted to the bottom of the euphotic zone [19-22]. These studies also showed that a third ecotype (eNATL), initially classified as a LL clade (LLI), preferentially lived at intermediate depth, reaching maximal concentrations in the vicinity of the thermocline. Comparative genomics revealed that these various ecotypes display a number of genomic differences, including distinct sets of genes involved in DNA repair pathways $[3,23,24]$. For instance, genes encoding DNA photolyases, which are involved in the repair of thymidine dimers, are found in HL and eNATL ecotypes, but not in "true" LL strains (i.e., LLII-IV clades). Besides this light niche specialization, a dramatic genome reduction has affected all Prochlorococcus lineages except the LLIV clade, situated at the base of the Prochlorococcus radiation. This streamlining process seemingly reduced their signal transduction and gene expression regulatory capacity, raising the question how Prochlorococcus cells sense environmental signals and translate them into cellular responses [25]. Thus, HL ecotypes possess only five sensor histidine kinases and seven response regulators, the two protein types that make up two-component regulatory systems in cyanobacteria $[4,24,26,27]$. As this set is considerably smaller than that found in most other prokaryotes, additional regulatory mechanisms are likely to exist. Recent experimental evidence indeed suggested the involvement of sophisticated post-translational regulatory mechanisms and a key role of non-coding RNAs (ncRNAs) in acclimation processes of Prochlorococcus marinus MED4 cells to a variety of environmental stresses [28].

The discovery of ecotypes with different light response characteristics, each with a specific depth distribution in the field calls into question the abovementioned interpretation of the delay in DNA synthesis initiation noticed in field populations by Vaulot and coworkers [7]. Comparative cell cycle dynamics of the $P$. marinus HLI strain MED4 and the LLII strain SS120 under similar light/dark conditions indeed showed that SS120 initiated DNA replication 1-2 h earlier than MED4 [6]. So, ecotypic differences may also explain this delay. In the present paper, we reexamine this issue by directly characterizing the effects of UV radiation on the cell cycle dynamics and gene expression patterns of L/D synchronized cultures of the HLI strain PCC9511.

\section{Results}

Comparative cell cycle dynamics of acclimated $P$. marinus PCC9511 cells grown in batch cultures with and without UV radiation

A first series of preliminary experiments using batch cultures of $P$. marinus PCC9511 was performed in order to examine the effects of UV exposure on cell cycle and growth. Cells were acclimated for several weeks to a modulated $12 \mathrm{~h} / 12 \mathrm{~h} \mathrm{~L} / \mathrm{D}$ cycle of photosynthetically available radiation (PAR) reaching about $900 \mu \mathrm{mol}$ photons $\mathrm{m}^{-2} \mathrm{~s}^{-1}$ at virtual noon (HL condition), or with modulated UV radiation added ( $\mathrm{HL}+\mathrm{UV}$ condition), the UV dose at noon reaching $7.6 \mathrm{~W} \mathrm{~m}^{-2}$ for UV-A and 0.6 $\mathrm{W} \mathrm{m}{ }^{-2}$ for UV-B (see additional file 1: Fig. S1). Samples were then taken every hour during three consecutive days and the DNA content of cells was measured by flow cytometry (Fig. 1). In both light conditions, Prochlorococcus population growth conformed to the slowgrowth case of Cooper and Helmstetter's prokaryotic cell cycle model [29], with only one DNA replication round per day. Indeed, as described before [6,7], Prochlorococcus DNA distributions always resembled the characteristic bimodal DNA distributions observed for eukaryotes, with a first discrete gap phase $\left(G_{1}\right)$, where cells possess one chromosome copy, preceding a well defined chromosome replication phase (S), followed by a second gap phase $\left(G_{2}\right)$, where cells have completed DNA replication but have not yet divided, and thus possess two chromosome copies (see additional file 2: Fig. $\mathrm{S} 2$ ). The $\mathrm{G}_{1} / \mathrm{S} / \mathrm{G}_{2}$ designation will therefore be used in the text hereafter. 


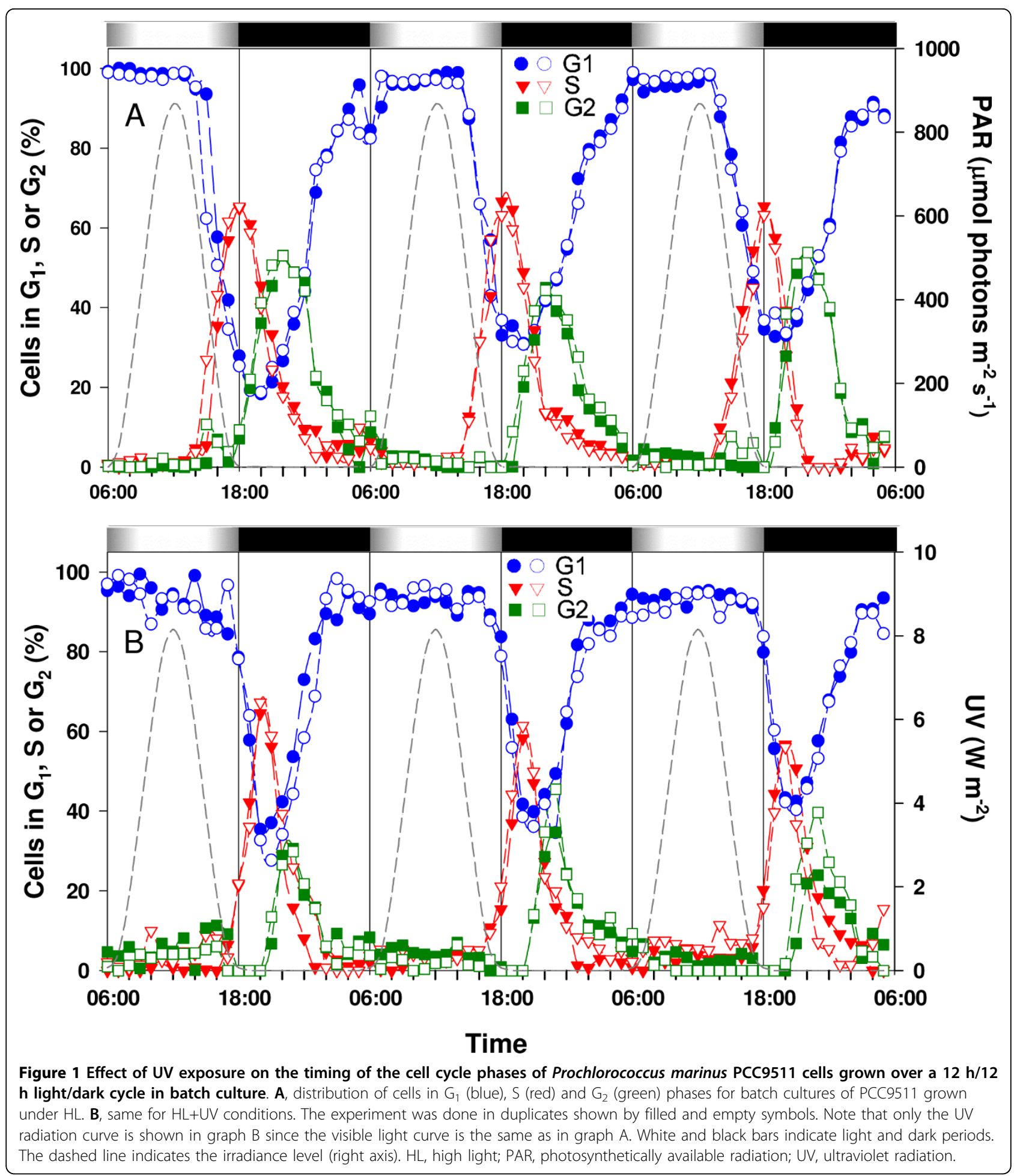

Figure 1 shows the time course variations of the percentages of cells in the different phases of the cell cycle. Under HL condition, cells started to enter the $S$ phase about $4 \mathrm{~h}$ before the light-to-dark transition (LDT) and the peak of S cells was reached exactly at the LDT. The first $G_{2}$ cells appeared at the LDT and the peak of $G_{2}$ cells was reached $4 \mathrm{~h}$ later. Most cells had completed division before virtual sunrise, as shown by a percentage of cells in $\mathrm{G}_{1}$ close to $100 \%$ at (or $1 \mathrm{~h}$ after) that time (Fig. 1A). PCC9511 cultures acclimated to HL+UV 
conditions showed a remarkable cytological response with regard to the timing of chromosome replication. In the presence of UV, entry into S was clearly delayed, with the onset of chromosome replication occurring about $1 \mathrm{~h}$ before the LDT and the maximum number of cells in $\mathrm{S}$ phase reached $2 \mathrm{~h}$ after the LDT. Entry into $\mathrm{G}_{2}$ was also delayed by $3 \mathrm{~h}$, but the peak of $\mathrm{G}_{2}$ cells was reached more quickly, so that it occurred on average only $1 \mathrm{~h}$ after that observed under the HL condition (Fig. 1B).

The faster progression of cells through $\mathrm{S}$ and $\mathrm{G}_{2}$ phases under HL+UV than HL only conditions in batch culture was confirmed by calculating the lengths of the $\mathrm{S}$ and $\mathrm{G}_{2}$ phases, which were shorter in the former condition (Table 1). Cells grown under HL+UV exhibited a higher level of synchronization (as shown by a lower synchronization index, $\mathrm{S}_{\mathrm{r}}$ ) than those grown under $\mathrm{HL}$ only. However, the calculated growth rates were not significantly different between the two conditions. Therefore, the dose of UV irradiation that was used in this experiment did not prevent cells from growing at near maximal rate despite the delay of entry in $S$ phase (Table 1). It must be noted that growth rates calculated from the percentages of cells in $\mathrm{S}$ and $\mathrm{G}_{2}\left(\mu_{\mathrm{cc}}\right)$ using the method described by Carpenter \& Chang [30] were systematically about $10 \%$ higher than those calculated from the change in cell number $\left(\mu_{\mathrm{nb}}\right)$. Since the latter method was used to assess the growth rate of continuous cultures (see below), these experiments in batch cultures were therefore useful to estimate the bias brought by these cell cycle-based growth rate measurements.

\section{Cell cycle dynamics of P. marinus PCC9511 cells in batch culture during shifts to a different light condition}

A second series of preliminary experiments in batch culture was performed to see i) whether changes in PAR level from modulated low light (LL; corresponding to a maximum irradiance level $\mathrm{E}_{\max }$ at noon $\sim 100 \mu \mathrm{mol}$ photons $\left.\mathrm{m}^{-2} \mathrm{~s}^{-1}\right)$ to modulated HL $\left(\mathrm{E}_{\max }\right.$ at noon $\sim 900$ $\mu$ mol photons $\mathrm{m}^{-2} \mathrm{~s}^{-1}$ ) would also affect the timing of the initiation of DNA replication in P. marinus cells and ii) how fast was the delay in chromosome replication observed when PCC9511 cells pre-acclimated to HL were suddenly exposed to HL+UV conditions.

When acclimated to modulated LL, P. marinus cells generally started chromosome replication slightly earlier (LDT minus $5 \mathrm{~h}$ ) than under HL conditions and the $\mathrm{S}$ phase maximum was also reached $1 \mathrm{~h}$ earlier (Fig. 2A). When shifted to HL, cells initiated DNA replication at the same time as in LL, but the peak of $\mathrm{S}$ cells was shifted to the LDT, as observed for HL acclimated cells. This event was accompanied by a notable increase in the peak height of the $\mathrm{S}$ cell maximum (from 48 to $85 \%)$ on the first day of increased PAR, but on the second day after HL shift, this percentage decreased to levels (ca. 65\%) comparable to those observed in HL acclimated cultures (compare Figs. 1A and 2A). Indeed, PCC9511 cells grew much faster under HL than LL conditions and the maximal growth rate (comparable to that of HL acclimated cells) was reached already on the first day of increased PAR (Table 2). This enhanced growth rate resulted from a dramatic shortening of the $G_{1}$ phase and, to a less extent, of the $G_{2}$ phase, whereas the $S$ phase was extended (Table 2). However, this rather long $\mathrm{S}$ phase, as compared to HL acclimated cells, suggests that cultures were not physiologically fully acclimated to the new light conditions, even two days after the shift.

In the second shift experiment, HL acclimated PCC9511 cultures were sampled during one complete $\mathrm{L} / \mathrm{D}$ cycle, then on the following two days were subjected to a modulated L/D cycle of HL+UV radiations. As for the HL+UV acclimated cells, UV exposure seemed to cause a delay in the initiation of DNA replication, but with the peak of $\mathrm{S}$ cells occurring 3 to $4 \mathrm{~h}$ after the LDT (Fig. 2B), instead of 2 h. Furthermore, although the UV dose received by the cells was the same in the UV acclimation and UV shift experiments,

Table 1 Growth parameters of batch and continuous cultures of Prochlorococcus marinus PCC9511 grown under a 12 h/12 h light/dark cycle under HL supplemented or not with UV radiations

\begin{tabular}{|c|c|c|c|c|}
\hline \multirow[b]{2}{*}{ Growth parameters* } & \multicolumn{2}{|c|}{ Batch Cultures } & \multicolumn{2}{|c|}{ Continuous Cultures } \\
\hline & $\mathrm{HL}$ & HL+UV & $\mathrm{HL}$ & HL+UV \\
\hline$\mu_{c c}\left(d^{-1}\right)$ & $0.67 \pm 0.05$ & $0.68 \pm 0.03$ & $0.69 \pm 0.09$ & $0.66 \pm 0.04$ \\
\hline$\mu_{n b}\left(d^{-1}\right)$ & $0.60 \pm 0.13$ & $0.62 \pm 0.11$ & n.a. & n.a. \\
\hline $\mathrm{T}_{\mathrm{G} 1}(\mathrm{~h})$ & $16.8 \pm 1.6$ & $18.4 \pm 0.8$ & $17.8 \pm 2.5$ & $19.0 \pm 1.5$ \\
\hline $\mathrm{T}_{\mathrm{S}}(\mathrm{h})$ & $4.03 \pm 0.30$ & $3.47 \pm 0.28$ & $3.71 \pm 0.77$ & $3.83 \pm 0.49$ \\
\hline $\mathrm{T}_{\mathrm{G} 2}(\mathrm{~h})$ & $3.97 \pm 0.30$ & $2.53 \pm 0.28$ & $2.95 \pm 0.31$ & $2.51 \pm 0.60$ \\
\hline$S_{r}$ & $32.4 \pm 2.2$ & $24.6 \pm 1.1$ & $27.2 \pm 1.2$ & $25.0 \pm 1.4$ \\
\hline
\end{tabular}

Values are averages $( \pm \mathrm{SD})$ of three consecutive days and two biological replicates

* Growth rates per day calculated from: cell cycle data $\left(\mu_{\mathrm{cc}}\right)$ or cell numbers $\left(\mu_{\mathrm{nb}}\right) ; \mathrm{T}_{\mathrm{G} 1}, \mathrm{~T}_{\mathrm{S}}, \mathrm{T}_{\mathrm{G} 2}$ : cell cycle phase duration in hours; $\mathrm{S}_{\mathrm{r}}$ : rate of synchronization estimated from the ratio $\left(\mathrm{T}_{\mathrm{S}}+\mathrm{T}_{\mathrm{G} 2}\right) /\left(\mathrm{T}_{\mathrm{G} 1}+\mathrm{T}_{\mathrm{S}}+\mathrm{T}_{\mathrm{G} 2}\right)$

n.a.: not applicable 


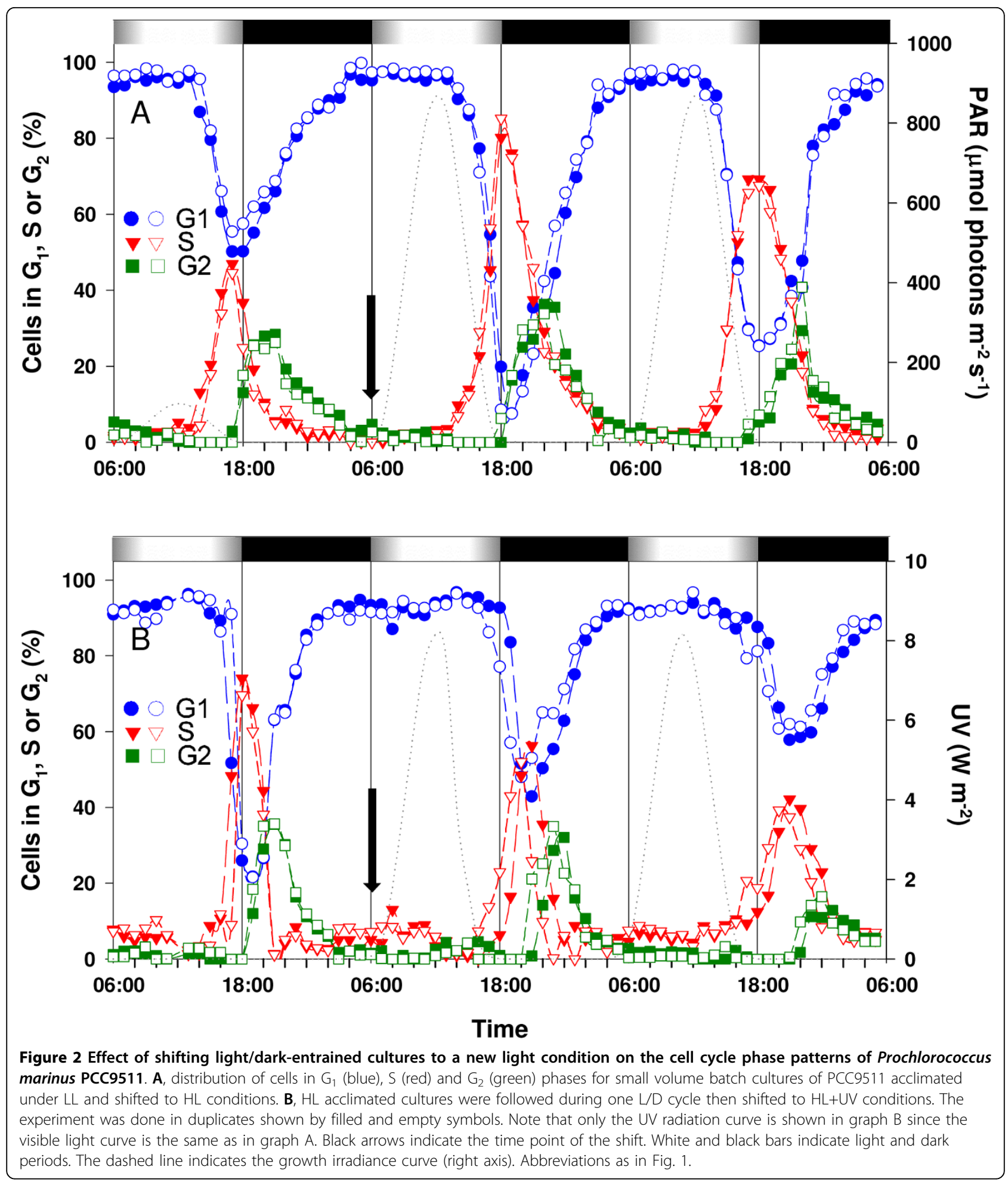

UV irradiation was clearly much more stressful for the cells in the second case, as they reacted by dramatically decreasing their growth rate (Table 3), an effect which was even more marked on the second day after switching the UV lamps on.
Comparative cell cycle dynamics of acclimated P. marinus PCC9511 cells grown in continuous cultures with and without UV radiation

Large volume, continuous cultures of $P$. marinus cells acclimated to either $\mathrm{HL}$ or $\mathrm{HL}+\mathrm{UV}$ conditions were 
Table 2 Growth parameters of PCC9511 batch cultures shifted from LL to HL during $12 \mathrm{~h} / 12 \mathrm{~h}$ L/D cycles

\begin{tabular}{cccc}
\hline Growth Parameters* & Cycle 1 (LL) & Cycle 2 (HL) & Cycle 3 (HL) \\
\hline$\mu_{\mathrm{cc}}\left(\mathrm{d}^{-1}\right)$ & $0.43 \pm 0.03$ & $0.67 \pm 0.01$ & $0.62 \pm 0.01$ \\
$\mu_{\mathrm{nb}}\left(\mathrm{d}^{-1}\right)$ & $0.37 \pm 0.04$ & $0.59 \pm 0.09$ & $0.58 \pm 0.05$ \\
$\mathrm{~T}_{\mathrm{G} 1}(\mathrm{~h})$ & $30.8 \pm 3.1$ & $16.7 \pm 0.3$ & $18.8 \pm 0.2$ \\
$\mathrm{~T}_{\mathrm{S}}(\mathrm{h})$ & $4.12 \pm 0.01$ & $5.15 \pm 0.14$ & $5.53 \pm 0.12$ \\
$\mathrm{~T}_{\mathrm{G} 2}(\mathrm{~h})$ & $3.89 \pm 0.01$ & $2.85 \pm 0.14$ & $2.47 \pm 0.12$ \\
$\mathrm{~S}_{\mathrm{r}}$ & $20.8 \pm 1.7$ & $32.4 \pm 0.4$ & $29.8 \pm 0.3$ \\
\hline
\end{tabular}

Values shown are averages ( \pm mean deviation) of two biological replicates * Growth rates per day calculated from: cell cycle data $\left(\mu_{c c}\right)$ or cell numbers $\left(\mu_{n b}\right) ; T_{G 1}, T_{S}, T_{G 2}$ : cell cycle phase duration in hours; $S_{r}$ : rate of synchronization estimated from the ratio $\left(T_{S}+T_{G 2}\right) /\left(T_{G 1}+T_{S}+T_{G 2}\right)$

used for gene expression analyses. These cultures were sampled for RNA eight times per day during three consecutive days. A shorter sampling interval (every $2 \mathrm{~h}$ ) was used during the DNA replication period (Fig. 3), to closely analyze transcriptome changes caused by UV radiation during this critical phase of the cell cycle. The pattern of $G_{1}, S$ and $G_{2}$ phases in $H L+U V$ was similar to that in the batch experiments, with the same $2 \mathrm{~h}$ delay of the $\mathrm{S}$ phase into the dark period (Fig. 1). However, in $\mathrm{HL}$ conditions, the $\mathrm{G}_{2}$ maximum in continuous culture occurred on average $1 \mathrm{~h}$ earlier than in batch cultures due to a shorter $G_{2}$ period and a better synchronization index of the whole population (Table 1). This is possibly linked to the particularly fast growth rate $\left(\mu_{\mathrm{cc}}\right.$ of $0.71 \mathrm{~d}^{-1}$, corresponding approximately to a $\mu_{\mathrm{nb}}$ of $0.64 \mathrm{~d}^{-1}$ ) observed in this experiment (Table 1 ). Another notable difference between the two sets of experiments is the fact that during the second and third day in the continuous HL+UV culture, there was a shoulder on the left of the S peak (Fig. 3), suggesting that a small percentage of cells already had entered into $\mathrm{S}$ phase $2 \mathrm{~h}$ before the LDT, though the bulk of the cell population replicated DNA only during the dark period. The comparison of $\mu_{\mathrm{cc}}$ between batch and continuous cultures clearly demonstrated that the latter were growing exponentially in both $\mathrm{HL}$ and $\mathrm{HL}+\mathrm{UV}$ conditions

Table 3 Growth parameters of PCC9511 batch cultures shifted from HL to HL+UV during $12 \mathrm{~h} / 12 \mathrm{~h}$ L/D cycles

\begin{tabular}{cccc}
\hline $\begin{array}{c}\text { Growth } \\
\text { Parameters* }\end{array}$ & $\begin{array}{c}\text { Cycle 1 } \\
(\mathbf{H L})\end{array}$ & $\begin{array}{c}\text { Cycle 2 (HL } \\
\text { +UV) }\end{array}$ & $\begin{array}{c}\text { Cycle 3 } \mathbf{H L} \\
+\mathbf{H V})\end{array}$ \\
\hline$\mu_{\mathrm{cc}}\left(\mathrm{d}^{-1}\right)$ & $0.69 \pm 0.02$ & $0.61 \pm 0.01$ & $0.45 \pm 0.00$ \\
$\mu_{\mathrm{nb}}\left(\mathrm{d}^{-1}\right)$ & $0.64 \pm 0.05$ & $0.45 \pm 0.02$ & $0.1 \pm 0.02$ \\
$\mathrm{~T}_{\mathrm{G} 1}(\mathrm{~h})$ & $18.0 \pm 0.6$ & $21.4 \pm 0.3$ & $29.3 \pm 0.2$ \\
$\mathrm{~T}_{\mathrm{S}}(\mathrm{h})$ & $3.67 \pm 0.14$ & $3.72 \pm 0.09$ & $6.25 \pm 0.03$ \\
$\mathrm{~T}_{\mathrm{G} 2}(\mathrm{~h})$ & $2.33 \pm 0.14$ & $2.28 \pm 0.09$ & $1.75 \pm 0.03$ \\
$\mathrm{~S}_{\mathrm{r}}$ & $25.0 \pm 0.7$ & $21.9 \pm 0.2$ & $21.5 \pm 0.1$ \\
\hline
\end{tabular}

Values shown are averages ( \pm mean deviation) of two biological replicates *Growth rates per day calculated from: cell cycle data $\left(\mu_{\mathrm{cc}}\right)$ or cell numbers $\left(\mu_{n b}\right) ; T_{G 1}, T_{S}, T_{G 2}$ : cell cycle phase duration in hours; $S_{r}$ : rate of synchronization estimated from the ratio $\left(T_{\mathrm{S}}+\mathrm{T}_{\mathrm{G} 2}\right) /\left(\mathrm{T}_{\mathrm{G} 1}+\mathrm{T}_{\mathrm{S}}+\mathrm{T}_{\mathrm{G} 2}\right)$ during the whole sampling period used for gene expression analyses.

\section{Effects of ultraviolet radiation on the whole transcriptome dynamics}

Microarray analyses were used to identify which genes were differentially expressed between HL and $\mathrm{HL}+\mathrm{UV}$ during the active phases of the cell cycle of $P$. marinus PCC9511, with the goal to understand the molecular bases of the delay of DNA replication in the latter condition. We made pairwise comparisons of microarray datasets corresponding to the same time points around the LDT in HL+UV and HL conditions, i.e. 15:00 (UV15 vs. HL15; corresponding to the $\mathrm{G}_{1}$ phase in each condition), 18:00 (UV18 vs. HL18), 20:00 (UV20 vs. HL20) and 22:00 (UV22 vs. HL22; corresponding to the $\mathrm{G}_{2}$ phase in each condition). To better analyze the changes in gene expression patterns occurring during the DNA synthesis (S) phase, we also compared samples taken at 20:00 in HL+UV and at 18:00 in HL (UV20 vs. HL18), respectively, as this corresponds to the maximum percentage of cells in $\mathrm{S}$ for each condition (see Fig. 3).

Overall, 217 genes of the 1,963 analyzed genes (11.1\%) showed statistically significant differential expression levels in all comparisons performed between the two light conditions, with a false discovery rate (FDR) $\leq 0.1$ using t-test and/or LIMMA analyses (including 115 genes with significant fold change (FC) values, i.e. with $\log _{2}(\mathrm{FC})>1$; see Fig. 4 and additional file 3: Table T1). The greatest number of differentially expressed genes was obtained for the UV18 vs. HL18 (136 genes, including 66 with $\log _{2}(\mathrm{FC})>1$; Fig. 4) and the UV20 vs. HL18 comparisons (86 genes, including 45 with $\log _{2}(\mathrm{FC})>1$; Fig. 4).

Hierarchical clustering analysis using Pearson's correlation of the whole expression dataset (averaged over 2 consecutive days) showed that for any given light treatment and time of the day, cultures A and B grouped well together (Fig. 5). This showed that experimental conditions influenced the expression data more than did technical and biological variability between replicates. Furthermore, whole transcriptomic profiles clustered according to the sampling time and/or cell cycle stage, since UV15 and HL15 corresponded to $\mathrm{G}_{1}, \mathrm{UV} 20$ and HL18 to S, and UV22 and HL22 to $G_{2}$. It is noteworthy that the two replicates of UV18 were not congruent, since sample B clustered close to HL15 and UV15, as expected for cells that are seemingly arrested in $G_{1}$, whereas sample A clustered with the HL18 dataset, i.e. according to sampling time. Finally, the HL20 dataset clustered with the UV22 and HL22 datasets, consistent with the fact that part of the population of the HL20 sample was already in $\mathrm{G}_{2}$ (see Fig. 3A). Thus, it seems 


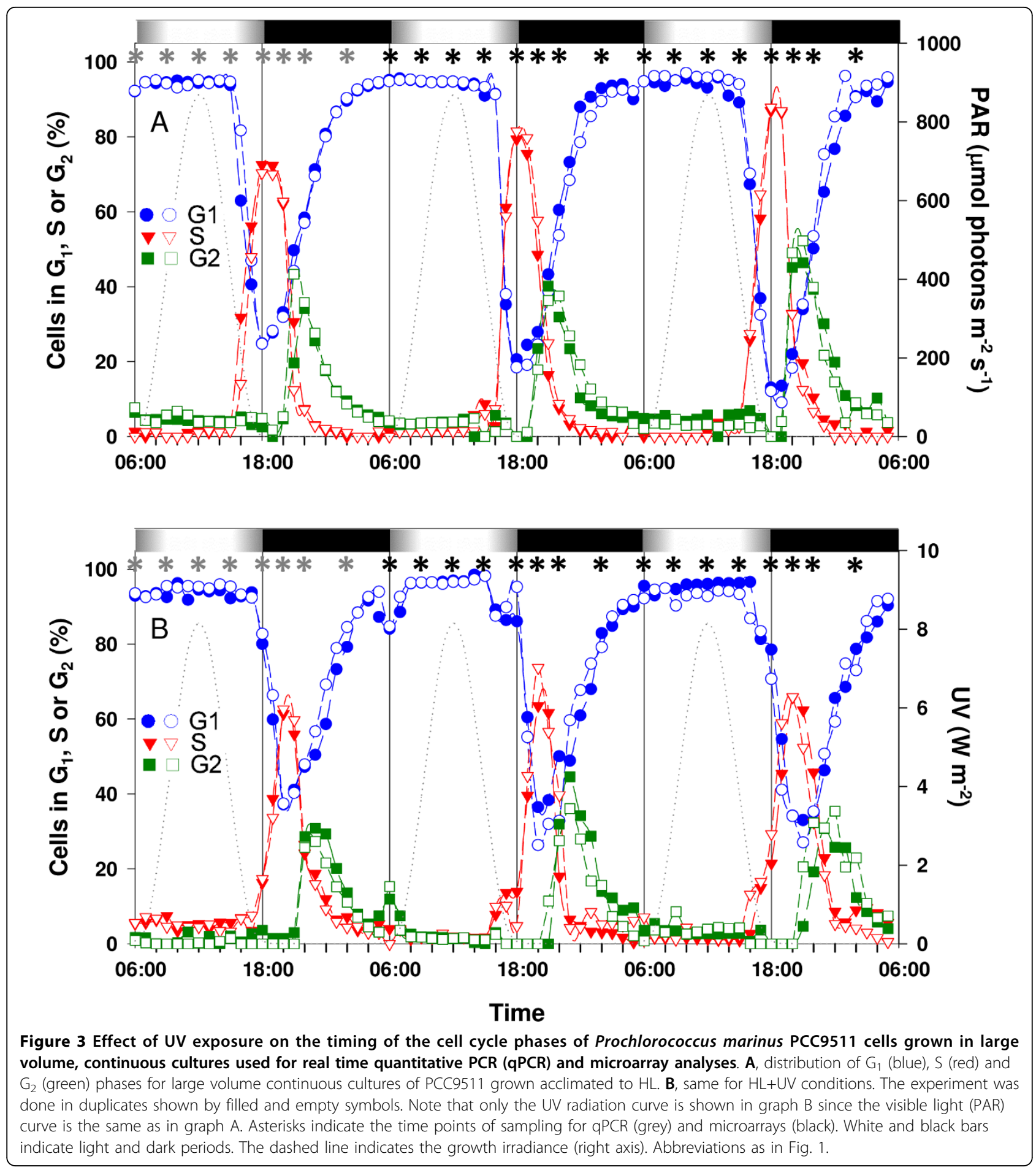

that the $S$ phase delay had a strong effect on the PCC9511 transcriptome, competing with the strong effect of diurnal rhythm, since most genes are lightregulated in these organisms [14].

Among the statistically significant genes mentioned above, only 115 genes (or 53.0\%) displayed fold changes higher than two-fold in HL $v s$. HL+UV timepoint pairwise comparisons (see Fig. 4 and additional file 3: Table T1). The following paragraphs discuss the most meaningful comparisons.

Eleven genes from this dataset were differentially expressed in UV15 vs. HL15 ( $\mathrm{G}_{1}$ phase) and may be involved in the cell response to UV exposure. Seven of them were upregulated under HL+UV (see additional 


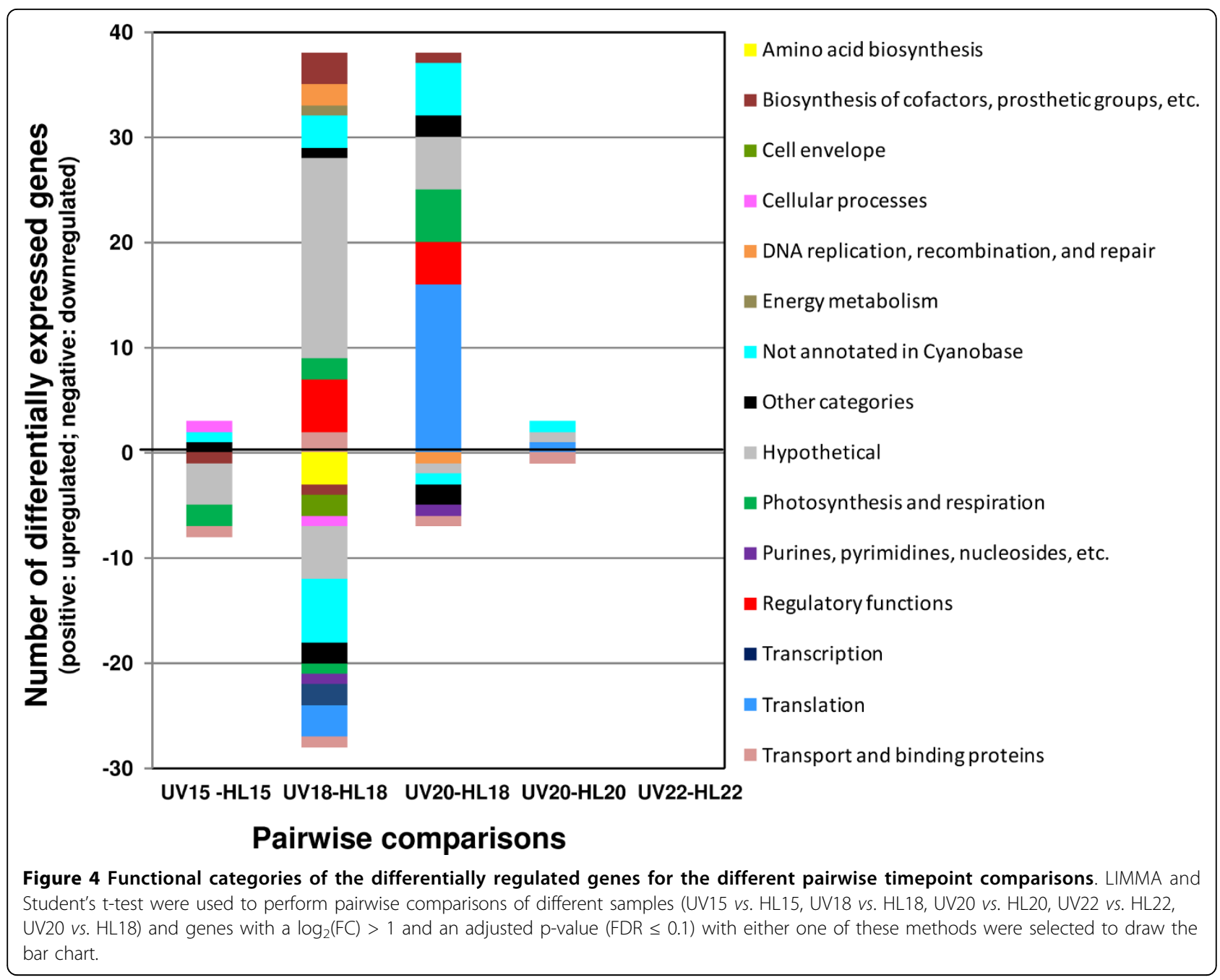

file 3: Table T1). These were one non-coding RNA (ncRNA, Yfr7; [28]), five photosynthetic genes, including PMM1118, one member of the high light inducible (hli) gene family (hli04), and PMM0743, an ortholog of slr0228, which encodes $\mathrm{FtsH}$, a protein involved in D1 repair and degradation in Synechocystis sp. PCC6803 [31]. Consistently with quantitative PCR analyses (see below), the PMM1697 gene encoding the type II $\sigma$ factor RpoD4 was downregulated at 15:00 in cultures exposed to $\mathrm{HL}+\mathrm{UV}$, though its p-value was statistically significant only before Benjamini and Hochberg $(\mathrm{BH})$ adjustment (FDR $\leq 0.1$; see additional file 3: Table T1).

The UV18 vs. HL18 comparison showed the largest number (66) of differentially expressed genes, as expected from the fact that cells were essentially in $G_{1}$ in the HL+UV condition, whereas in HL most cells were in S (Fig. 3). One third of these genes (24) had no assigned function. The gene coding for one of the main subunits of the ATP synthase (atpA; PMM1451) was downregulated under $\mathrm{HL}+\mathrm{UV}$ and most genes coding for other subunits of this complex (atpD, E, F, G and $H$, encoded by PMM1452, PMM1439 and PMM1453-1455, respectively) were also very close to the statistically significant fold change (FC) cutoff (see additional file 3: Table T1). If these relative reductions in the transcript levels of atp genes at 18:00 in the cells grown in HL + UV actually translated into a lower amount of ATPase produced, this could have resulted into a relative decrease (or delay) in energy supply of these cells during the dark period. Two key genes for the synthesis of RNA polymerase, i.e. rpoA (PMM1535), encoding the $\alpha$ subunit, and $P M M 0496$, encoding the major $\sigma$ factor RpoD1/SigA, were also expressed at much lower levels under HL+UV than HL conditions at 18:00. Assuming that this reduction resulted in correspondly lower protein levels, it is possible that the overall transcriptional activity of UV-acclimated cells could be reduced after the LDT. Since PMM1629, encoding the type II $\sigma$ factor RpoD8, was upregulated under $\mathrm{HL}+\mathrm{UV}$, it is possible that RpoD8 replaces RpoD1 in the early dark period. 


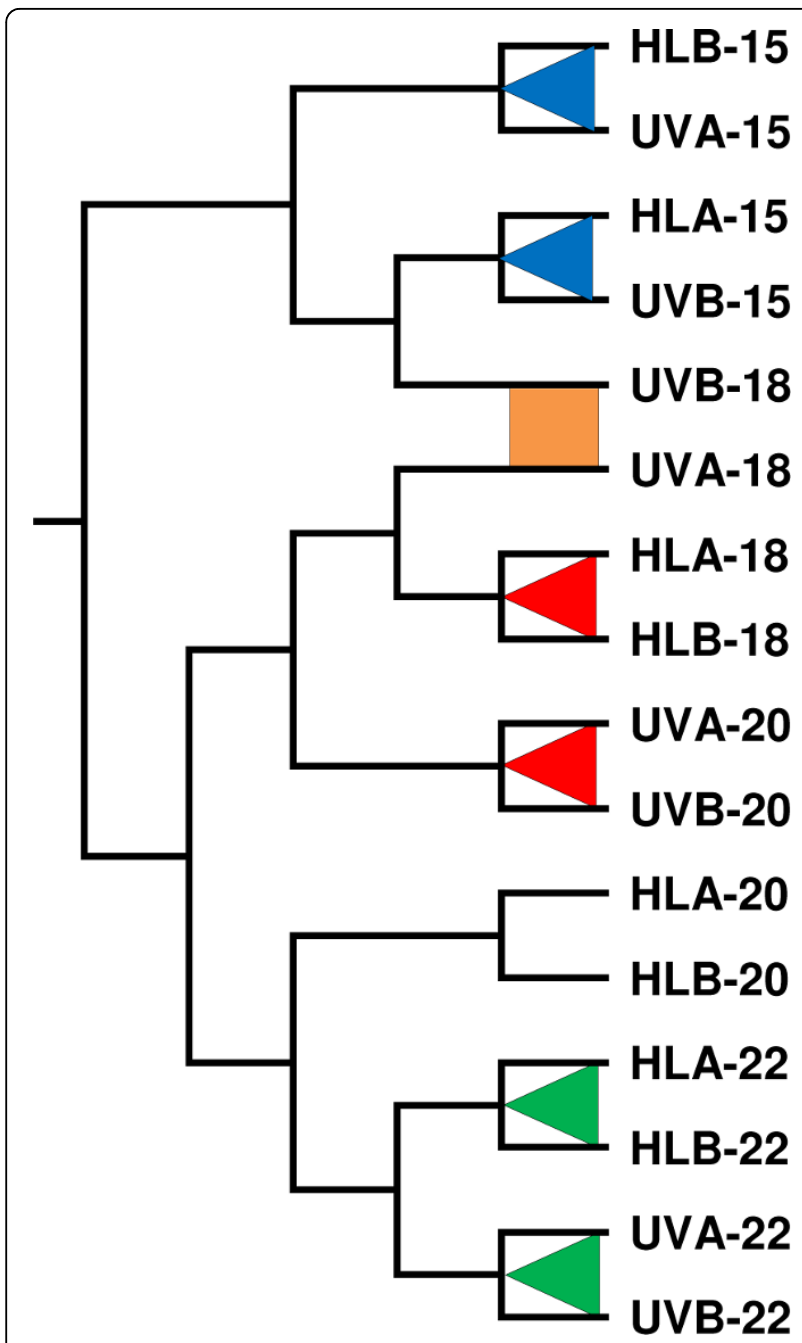

Figure 5 Hierarchical clustering analysis of the microarray dataset. Clustering analysis was performed on a selected gene list (819 genes) generated by one-way ANOVA with an adjusted $p$-value (FDR $\leq 0.1)$ and after combining data from days 1 and 2 for both cultures (A and B) and light conditions ( $\mathrm{HL}$ and $\mathrm{HL}+\mathrm{UV}$ ) and at each time point. The dendrogram was produced as described in the text. Colored triangles correspond to the different cell cycle phases with $G_{1}$ in blue, $S$ in red and $G_{2}$ in green. The orange square indicates the stage where cells exhibit a delay in the $\mathrm{S}$ phase under $\mathrm{HL}+\mathrm{UV}$ condition

The transcriptional regulator gene pedR (PMM0154) and two genes potentially involved in DNA repair (PMM1528 and PMM0843, encoding respectively an $\mathrm{HNH}$ endonuclease and a possible TldD-like modulator of DNA gyrase) were also upregulated at 18:00 in the $\mathrm{HL}+\mathrm{UV}$ condition (see additional file 3: Table T1), suggesting that the latter genes were directly or indirectly involved in the repair of DNA damage caused by UV irradiation.

Surprisingly, the UV20 vs. HL18 comparison also revealed a high number of up- or downregulated genes
(45), suggesting that although cells were predominantly in S phase in both light conditions, UV irradiation during the day altered differentially the pattern of expression of genes from the different metabolic pathways around the LDT. Among annotated genes of this dataset, those most represented belonged to the functional categories of ribosomal proteins (14, all upregulated under HL+UV; see Fig. 4 and additional file 3: Table T1). However, most of these genes were also upregulated in the HL20 vs. HL18 comparison (data not shown), indicating that the diel expression pattern of these key translation genes was less affected by UV stress than by daytime, at least around the LDT period. Most of the genes that were differentially regulated in the UV20 vs. HL18 but not in the HL20 vs. HL18 comparisons belonged to the conserved hypothetical gene category (data not shown).

Few genes were differentially expressed between HL and $\mathrm{HL}+\mathrm{UV}$ during the dark period (4 genes in the UV20 vs. HL20 and none in the UV22 vs. HL22 comparisons, corresponding to the $G_{2}$ phase and the beginning of cell division, respectively; Fig. 4) and most of them were not assignable to a characterized functional category (see Fig. 4 and additional file 3: Table T1). This suggests that the effect of UV irradiation on the PCC9511 transcriptome was no longer significant only a few hours after the LDT.

Altogether, surprisingly few genes belonging to pathways directly linked to the cell cycle crossed the statistical significance $(\mathrm{FDR}<0.1)$ and $\mathrm{FC}\left[\log _{2}(\mathrm{FC})<-1\right.$ or $>$ 1] cutoffs (see additional file 3: Table T1). To insure that this was not due to a lack of sensitivity of the arrays and to gain more detailed information on the behavior of this gene category, seventeen genes were selected and subsequently analyzed by real time quantitative PCR (hereafter qPCR). This set includes genes that were either differentially expressed in microarray analyses or representative of key processes, including DNA replication, cell division, DNA repair, transcriptional regulation and the circadian clock. All genes that exhibited significantly different expression levels (i.e., with FDR $\leq 0.1$ ) in one of our comparisons in microarray analyses showed a similar response (up- or downregulation) in qPCR experiments [Pearson's correlation coefficient of 0.86 for pairwise comparisons with a $\log _{2}$ $(\mathrm{FC})<-0.5$ or $>0.5]$.

\section{Expression patterns of genes involved in the initiation of} chromosome replication and cell division are strongly affected by UV radiation

Three genes were selected as representatives of the DNA replication and cell division pathways, dnaA (PMM0565), encoding the DNA replication initiation protein DnaA, ftsZ (PMM1309), encoding the tubulin 
homolog GTPase protein FtsZ, which forms a ringshaped septum at midcell during cell division, and sepF (PMM0395), encoding a protein involved in the assembly and stability of the FtsZ ring [32]. The transcript levels of all three genes exhibited strong temporal variations during the diel cycle in both light conditions (Fig. 6). Under HL+UV conditions, although expression levels of both dnaA and fts $Z$ genes significantly increased at 15:00 compared to the 6:00 time point, the expression level was 3- to 5-fold lower than under HL at 15:00. The sepF gene expression pattern was characterized by a strong peak at the LDT in HL, but like for the other two genes, the diel variations of sepF expression levels were dramatically reduced in UV-irradiated cells. In both light conditions, the sepF expression was maximum during the $\mathrm{S}$ phase (Fig. $6 \mathrm{C}$ ).

\section{Transcript levels of DNA repair genes are moderately affected by UV radiation}

Analyses of diel expression patterns of six genes representative of different DNA repair pathways were compared between HL and HL+UV conditions (Fig. 7). These patterns were very different among the six genes, suggesting a refined orchestration of the different pathways. A first set of DNA repair genes, including $p h r A$ (PMM0285), which codes for a DNA photolyase and uvrA (PMM1712), encoding the subunit A of the excinuclease UvrABC, an enzyme of the nucleotide excision DNA repair (NER) pathway, was strongly expressed during the light period. Their expression levels followed more or less closely the diel cycle of irradiance (Fig. 7A). Interestingly, the relative expression levels of both genes were already high under HL and exposure to UV radiations did not provoke any further increase of these levels, even at midday. The only notable difference between the HL and HL+UV profiles was a slightly higher expression level at 9:00 am for both genes in the former condition (Fig. 7A).

Expression levels of mutS (PMM1645), a gene involved in the DNA mismatch repair (MMR) pathway, rose throughout the light period at the same rate in both light conditions, peaked right before the peak of $\mathrm{S}$ cells (i.e. $3 \mathrm{~h}$ before the LDT in HL and at the LDT in $\mathrm{HL}+\mathrm{UV}$ ), then decreased during the dark period (Fig. 7B). In sharp contrast with other DNA repair genes, the ruvC gene (PMM1054), which encodes the subunit $\mathrm{C}$ of the RuvABC resolvase endonuclease, an enzyme involved in recombinational DNA repair processes by homologous recombination, was downregulated during the daytime and was only induced at the LDT (Fig. 7B). It showed no response to the addition of UV radiation.

Among all DNA repair genes, the diel expression pattern of recA (PMM1562), which encodes an ATPase involved in repair of DNA double-strand breaks (DSBs)
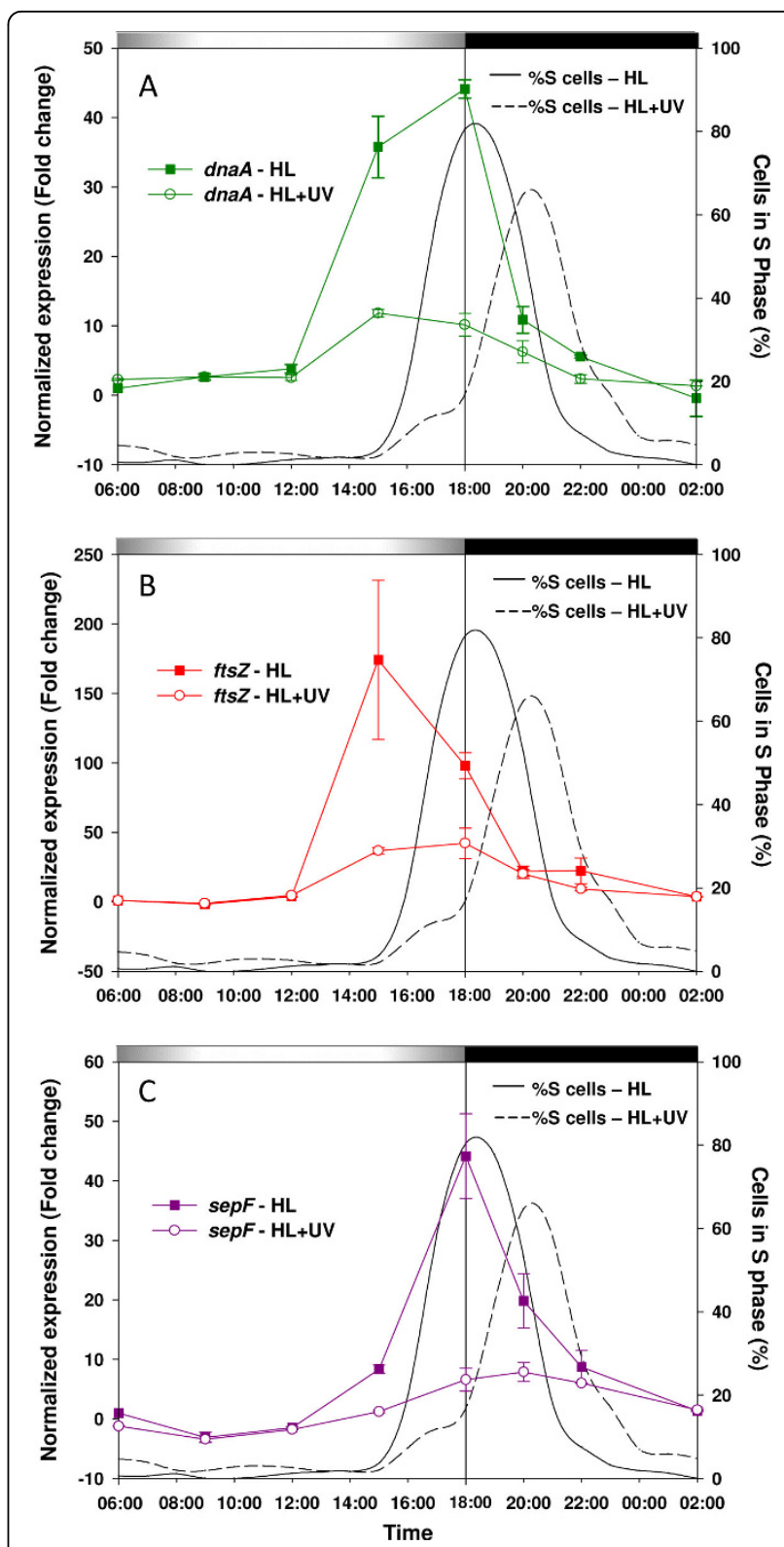

Figure 6 Gene expression patterns of L/D-synchronized Prochlorococcus marinus PCC9511 cultures under HL and UV growth conditions, as measured by qPCR. A, dnaA. B, ftsZ. C, sepF. The percentage of cells in the $\mathbf{S}$ phase of the cell cycle under $\mathrm{HL}$ (solid line) and HL+UV (dashed line) are also shown for comparison. Error bars indicate mean deviation for two biological replicates. For each graph, transcript levels were normalized to the reference time point 6:00 in $\mathrm{HL}$ condition. Grey and black bars indicate light and dark periods.

by homologous recombination, was seemingly the most affected by the presence of UV radiation. This pattern closely resembled that of $s e p F$, with expression maxima concomitant with the $\mathrm{S}$ peak in both light conditions (i. e. delayed in HL+UV; Fig. 7C). However, in contrast to $s e p F$, the height of the expression peak (normalized to 

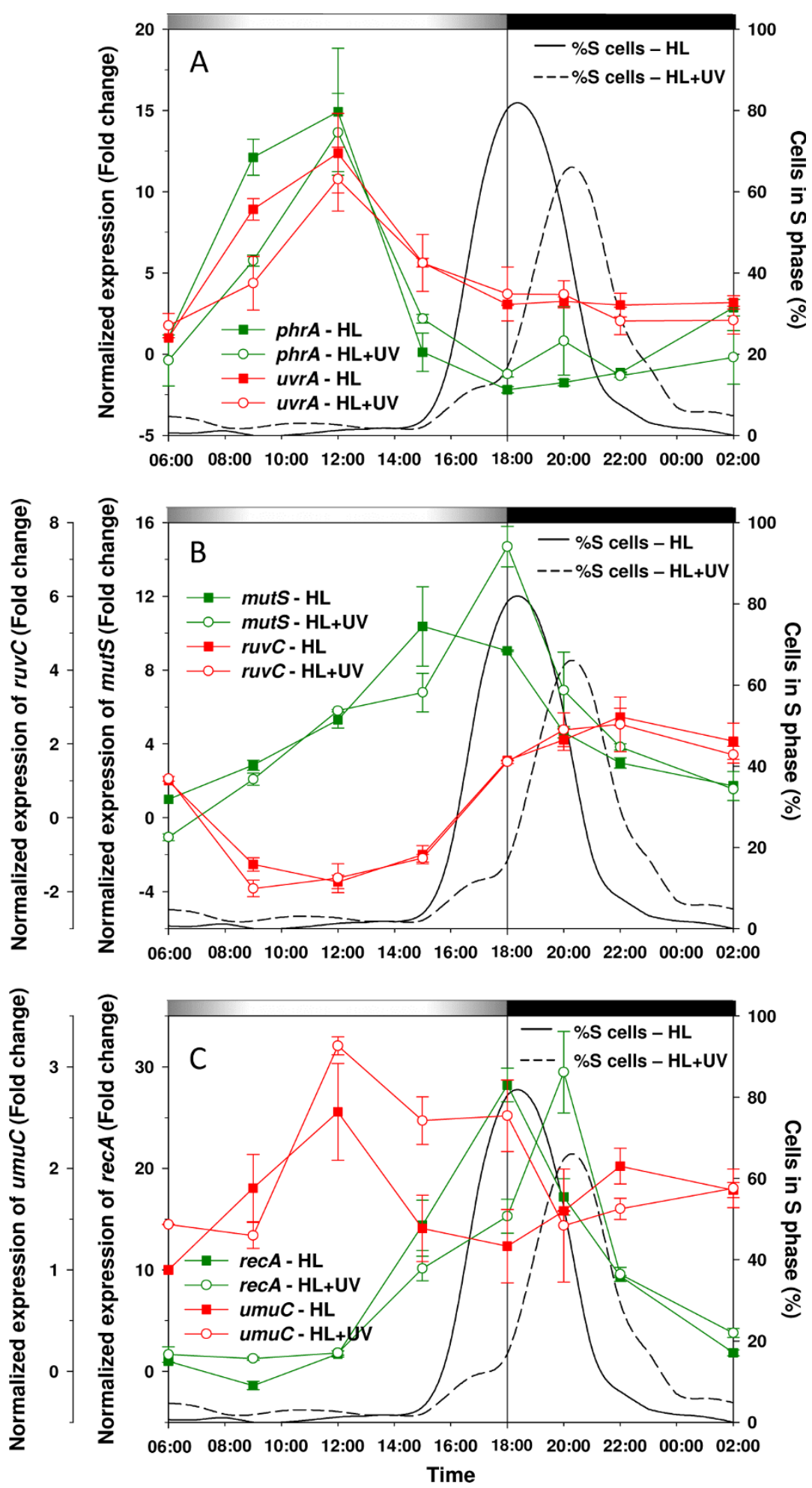

Figure 7 Gene expression patterns of L/D-synchronized Prochlorococcus marinus PCC9511 cultures under HL and UV growth conditions, as measured by qPCR. A, phrA and uvrA. B, mutS and ruvC. C, recA and umuC. The percentage of cells in the $S$ phase of the cell cycle under HL (solid line) and HL+UV (dashed line) are also shown for comparison. Error bars indicate mean deviation for two biological replicates. For each graph, transcript levels were normalized to the reference time point 6:00 in HL condition. Grey and black bars indicate light and dark periods. 
the 6:00 level in $\mathrm{HL}$ ) was similar between $\mathrm{HL}$ and $\mathrm{HL}$ +UV conditions (Fig. 7C). The temporal expression pattern of umuC (PMM0937), encoding a subunit of the error-prone polymerase $\mathrm{V}$ (PolV), was also somewhat affected by UV exposure, since in HL+UV, the gene remained highly expressed for $8 \mathrm{~h}$ after the midday maximum, whereas in HL only, umuC gene expression decreased sharply after the noon expression peak (Fig. 7C). This suggests that cells which were exposed to UV irradiation before entering $S$ phase might use the DNA translesion synthesis (TLS) pathway [33] in order to overcome UV-induced lesions potentially blocking DNA replication.

\section{Global transcription regulators and circadian clock genes are mildly affected by UV stress}

RNA polymerase sigma factors are transcriptional regulators involved in the response of cyanobacteria to a variety of stress conditions [34]. The Prochlorococcus marinus PCC9511 genome encodes five sigma factors [4], which have been named here mainly following the nomenclature used for Synechococcus sp. PCC7942 [35] (see Cyanorak database: http://www.sb-roscoff.fr/Phyto/ cyanorak/). This includes one member of the principal group 1 sigma factor (PMM0496, RpoD1), and four members of the group 2 sigma factors (PMM1697, RpoD4; PMM1289, RpoD6; PMM0577, RpoD7 and PMM1629, RpoD8), of which RpoD7-8 are specific for marine picocyanobacteria [34]. In the present study, we used a qPCR approach to examine the expression of rpoD4 and rpoD8, which were previously shown to have very distinct diel patterns under modulated diel cycles of PAR [14,36]. The rpoD8 gene was upregulated earlier in HL than HL+UV conditions, with equivalent expression at noon under both growth conditions, then downregulated during the rest of the day with a greater decrease throughout the subjective night period under HL+UV growth conditions (Fig. 8A). This pattern was completely the opposite of rpoD4, which was expressed at a low level until noon in HL (or until 15:00 in HL $+\mathrm{UV})$, was strongly upregulated at the LDT, then returned to the same expression level as at 6:00 (or even less in $\mathrm{HL}+\mathrm{UV}$ ) for the rest of the dark period (Fig. 8A).

The lexA gene (PMM1262) encodes a transcriptional regulator, which in Escherichia coli governs the SOS DNA damage repair response [37]. Like rpoD4, the lexA RNA level was the lowest during the morning hours, then strongly increased after midday so that expression was maximal at the LDT and decreased slowly thereafter (Fig. 8B). The pattern was similar in both light conditions, except that the peak in $\mathrm{HL}+\mathrm{UV}$ was slightly lower.

Two genes linked to the circadian clock machinery were also studied, kaiB (PMM1343), encoding one of the only two core clock proteins (since all
Prochlorococcus strains lack KaiA [36]) and sasA (PMM1077), coding for a two-component sensory transduction histidine kinase which relays clock output signal to downstream genes [38]. In HL, the level of $\mathrm{kaiB}$ mRNA decreased during the first hours of the light period, reaching a minimum at noon and then increasing until 20:00, when it reached an expression level similar to the 6:00 reference level (Fig. 8C). In $\mathrm{HL}+\mathrm{UV}$, kaiB expression pattern was generally the same as in $\mathrm{HL}$, except that its relative expression level was two-fold lower at noon, then increased progressively to reach the reference expression level at approximately 2:00. As already noted in a previous study [14], diel changes in kaiC gene (PMM1342) expression levels were very low, with no significant differences under $\mathrm{HL}$ and $\mathrm{HL}+\mathrm{UV}$ growth conditions (data not shown).

A diel cycle in the transcript levels of the sasA gene was also observed. In HL, it roughly followed that of $k a i B$ except that there was no mimima at noon, but rather a long period of downregulation lasting from 9:00 to 18:00, then a slight upregulation at the beginning of the night (Fig. 8C). In the presence of UV, the relative sasA expression levels were lower than in HL during most of the day, consistent with the effect of UV irradiation on kaiB RNA levels. The most notable difference between the two light conditions is (as for $\operatorname{ruvC}$ ) that the switch from down- to upregulation of sasA was delayed in $\mathrm{HL}+\mathrm{UV}$ and concomitant with the $\mathrm{S}$ peak (Fig. 8C), suggesting a possible involvement of circadian clock output signals on timing of cell cycle progression in PCC9511.

\section{Discussion}

Importance of the modulated character of UV radiation and of light history on the response of Prochlorococcus cells to UV stress

Several field studies using on-deck incubations have suggested that the marine cyanobacterium Prochlorococcus is particularly susceptible to the direct (or indirect, i.e. via the generation of reactive oxygen species) effects of UV irradiation, in particular in comparison to the cooccurring and phylogenetically closely related genus Synechococcus, which is seemingly much more resistant to UV stress $[39,40]$. This apparent sensitivity has been attributed in part to the tiny size of Prochlorococcus cells as well as their streamlined genomes, encompassing a minimal gene complement for a phototroph and hence reduced UV protection machinery [23,25,41]. Still, Prochlorococcus is very abundant in the upper layer of most oligotrophic waters (with the notable exception of the $\mathrm{S}$ Pacific gyre; see [3]) and can sustain high growth rates in near surface, UV-irradiated waters [7,8,42-44].

In order to better understand the molecular mechanisms by which Prochlorococcus manages to cope with 

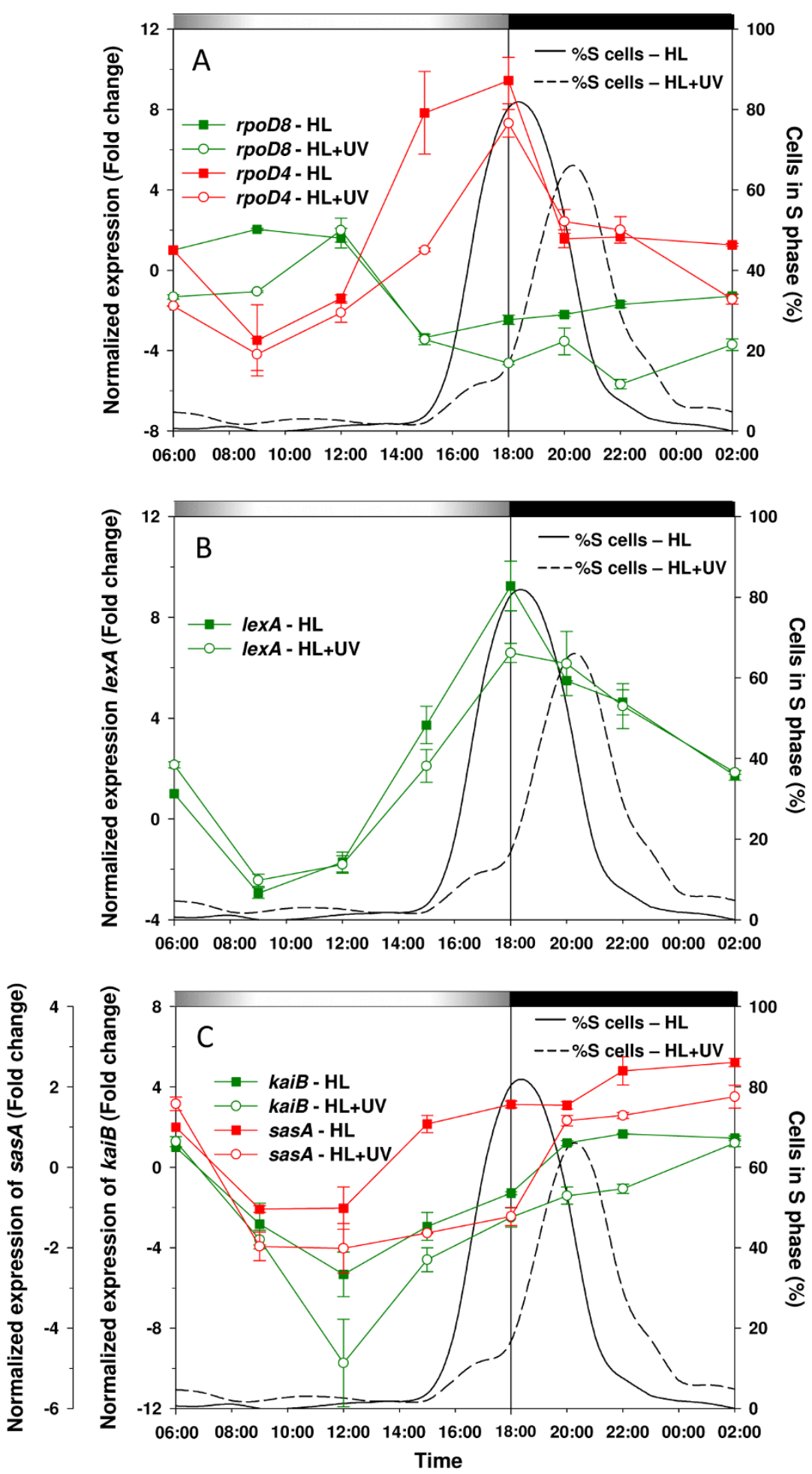

Figure 8 Gene expression patterns of L/D-synchronized Prochlorococcus marinus PCC9511 cultures under HL and UV growth conditions, as measured by qPCR. A, rpoD8 and rpoD4. B, lexA. C, kaiB and sasA. The percentage of cells in the S phase of the cell cycle under $\mathrm{HL}$ (solid line) and HL+UV (dashed line) are also shown for comparison. Error bars indicate mean deviation for two biological replicates. For each graph, transcript levels were normalized to the reference time point 6:00 in HL condition. Grey and black bars indicate light and dark periods. 
UV stress, we grew $P$. marinus strain PCC9511 under quasi natural light conditions by using a customdesigned illumination system which provided a modulated L/D cycle of PAR and UV radiation. This system induced a very tight synchronization of cell cycle and division (Figs. 1 and 3). Most studies that have analyzed UV effects on cyanobacteria thus far have been performed on asynchronously growing cells either by abruptly subjecting cultures to short-term UV stress (see e.g. [45-47]) or longer term acclimation to constant UV exposure $[48,49]$. The long term (acclimation) response of cells is known to be significantly different from the short term (shock) response, as it involves different sets of genes and regulation networks [48]. Yet, the modulated character of UV stress in nature, its cooccurrence with high light stress (also modulated) and the existence of long, dark recovery periods (i.e., nights) are also very important factors to take into account to fully understand how cells can acclimate to UV stress in nature. The dynamic aspect of this stress triggers a succession of signalling, gene regulation and/or repair pathways that lead to a temporally complex, coordinated response [50]. This finely tuned orchestration of the transcriptome and metabolome cannot be observed after merely subjecting cultures to a continuous (and often harsh) UV treatment, as it generally provokes a "distress" response that may eventually activate programmed cell death [51-53]. In our experiments, even though $P$. marinus sp. PCC9511 was growing at similar rates (ca. 1 division per day) in $\mathrm{HL}$ and $\mathrm{HL}+\mathrm{UV}$ conditions (Figs. 1 and 3; Table 1), this strain could not tolerate a sudden shift from HL to $\mathrm{HL}+\mathrm{UV}$ conditions, as this provoked a sharp decrease of its growth rate (Fig. 2B and Table 3) and ultimately death of the culture within a few days (not shown). To successfully acclimate our cultures to our experimental $\mathrm{HL}+\mathrm{UV}$ conditions, we therefore had to increase the UV dose incrementally with several days of acclimation at each step (see methods). Thus, acclimation of Prochlorococcus cells to UV stress is the result of a very subtle balance between the light environment experienced by cells in their specific niche (encompassing diel variations of visible and UV radiations) and a precise temporal succession of metabolic and repair processes that closely matches the ambient level of stress at any time of the day. Hence, attempts to sample cells from their natural environment and to incubate them in other (even slightly different) conditions, (as usually done to study the effects of UV stress in situ $[39,40]$ might well disrupt this fragile balance and rapidly lead to cell death.

It must be stressed that i) this hypothesis does not necessarily apply to other cyanobacteria that have a larger variety of UV protection systems [53] or at least (in the case of marine Synechococcus) a larger set of DNA repair genes (e.g. several putative photolyases), conferring them with a better resistance to UV stress, and ii) PCC9511 seems to cope with high light much better than with UV shock, since after cultures were shifted from LL to HL, their growth rate increased to one doubling per day by the day after the shift (Table 2). In contrast, LL-adapted Prochlorococcus spp. strains (such as SS120 or MIT9313) seemingly need to be acclimated incrementally to higher irradiances [54].

\section{Molecular bases of the chromosome replication delay}

One of the main results of the present study is that $P$. marinus PCC9511 can acclimate to relatively high doses of UV irradiation (commensurate with those that cells can experience in the upper mixed layer of oceans) by delaying DNA synthesis (S phase) towards the dark period. This strategy could reduce the risk of UV-induced replication errors [50]. It is probable that this delay is also needed for cells to repair UV-induced damages to DNA accumulated during the period preceding chromosome replication. In UV-irradiated cultures, we sometimes observed that a minor fraction of the population seemingly initiated chromosome replication at 15:00 (i.e. similar to the HL condition), as suggested by the shoulder to the left of the $\mathrm{S}$ peak before dusk (Fig. 3B). However, the absence of any skew on the left of the corresponding $G_{2}$ peak suggests that these cells either had an extended $\mathrm{S}$ phase (i.e. were temporarily blocked in S) or died before completing DNA replication. The maintenance of a high growth rate under $\mathrm{HL}+\mathrm{UV}$ conditions favors the former hypothesis.

Most UV-irradiated cells could not enter the S phase before complete darkness. One may wonder whether this observation is compatible with the occurrence of a UV stress-induced cell cycle "checkpoint", i.e. "a regulatory pathway that controls the order and timing of cell cycle transitions and ensure that critical events such as DNA replication and chromosome segregation are completed with high fidelity" [55]. If it exists, this checkpoint could be a "DNA replication initiation checkpoint", i.e. located before the $\mathrm{G}_{1}-\mathrm{S}$ transition. However, this hypothesis would not account for the previously mentioned small percentage of the population that was seemingly blocked in S. The occurrence of a "DNA replication completion checkpoint" was suggested for UV-C irradiated E. coli cells [56]. Cells in $G_{1}$ could not start chromosome replication while $S$ cells could not complete replication and hence divide; only cells already in $G_{2}$ at the time of irradiation were able to complete cytokinesis. In our case, however, because of the tight synchronization of the population, virtually no cell was sufficiently advanced in the cell cycle during the pre-dusk period to complete cytokinesis. 
It is generally thought that checkpoints are controlled by specific protein complexes involved in signaling (photoreceptors) and/or checking [57]. Thus, Prochlorococcus might possess a UV sensor which, when detecting these wavelengths, could launch a cascade of controlling mechanisms ultimately stopping the replication machinery. A UV-B sensor was characterized in the diazotrophic cyanobacterium Chlorogloeopsis sp. PCC6912 and was shown to mediate the induction of mycosporine-like amino acids synthesis [58]. However, no evidence for such a UV sensor is available in Prochlorococcus and, as argued later in this paper, its presence is rather unlikely. Recently, Cooper [59] proposed that checkpoints may in fact result from purely internal controls. It is possible that PCC9511 cells actually entered the early S phase but that the extensive occurrence of replication fork stalling due to accumulated DNA lesions and the elevated need for recovery of the replication process by lesion removal and replisome reloading [60] slowed down or even arrested the whole DNA synthesis process for a few hours, therefore explaining the observed delay without any need for a light sensing signal. The fact that UVacclimated cultures did not show any obvious decrease in their overall growth rate indicates that if stalling of replication forks occurred, efficient DNA repair mechanisms must have allowed those cells blocked in S to restart and complete chromosome replication.

\section{UV stress leads to the downregulation of DNA replication and cell division genes}

To further our understanding of the molecular bases of the observed delay in S phase completion, we analyzed the expression of key genes involved in chromosome replication and cell division. As is typically observed in model bacteria $[61,62]$, the $d n a A$ gene, encoding the master initiator protein of chromosome replication, was induced just before entry of cells into the $\mathrm{S}$ phase. Although an increase in $d n a A$ expression occurred at the same time under $\mathrm{HL}$ and $\mathrm{HL}+\mathrm{UV}$, its level of expression was considerably lower in the latter condition. It is well known in Escherichia coli that initiation of chromosome replication depends on reaching a threshold level of DnaA protein [63]. Thus, it is plausible that the low amounts of $d n a A$ transcripts at 15:00 in UV-irradiated PCC9511 cells (as compared to those in $\mathrm{HL}$ ) may have resulted in a decreased rate of DnaA protein accumulation in the cell, resulting in a several hour delay in the time at which the DnaA threshold concentration is reached. No homologs of regulators (e.g. seqA, dam, hda) known in other bacteria to control the mode of action of DnaA [64] have yet been identified in PCC9511. Still, one possible regulatory mechanism may involve ATP, since it is a necessary co-factor transforming the inactive form of DnaA (DnaA-ADP) into its active form (DnaA-ATP), capable of initiating chromosome replication [65]. We hypothesize that the lowered expression levels of ATP synthase genes in HL+UV during the daytime, as seen both in microarray (for atpA, $D, E, F, G$ and $H$; see above) and qPCR analyses (for atpD and atpH; see additional file 4: Fig. S3) could have caused a decrease in intracellular ATP levels that might have also contributed to delayed DnaA induction activity in PCC9511.

Even if the lowered expression of $d n a A$ is sufficient by itself to explain the observed $S$ phase delay, it appears that UV exposure also strongly affected the expression of several (and possibly all) genes involved in cell division, including fts $Z$ and sepF, both encoding key components of the divisome [66]. This similar behavior suggests that the DNA replication and cell division machineries could be controlled by the same regulatory network, though the timing of maximal expression varies between genes (Fig. 6). SepF is thought to be involved in the polymerization and stability of FtsZ filaments. Marbouty and co-workers [32] showed in vitro that SepF binds to preassembled FtsZ polymers, suggesting that SepF is required only after all the FtsZ protofilaments needed to make a Z-ring have been synthesized. This hypothesis is consistent with the delay observed between the peaks of expression of fts $Z$ and sepF in both light conditions.

\section{DNA repair genes are activated under high light}

Another surprising result from this study is that UV exposure did not result in any significant upregulation of DNA repair genes (relative to HL conditions), including some which are known to be involved in repairing damage specifically induced by UV stress. This includes the $p h r A$ gene, which encodes an enzyme involved in repair (by photoreactivation) of the most frequent DNA lesions in response to UV, i.e. cyclobutane pyrimidine dimers (CPDs; [67]). Our results demonstrate that phrA is also strongly expressed under HL, with a pattern during the day that somewhat matched the irradiance curve, suggesting that the expression of this gene is strongly regulated by light. Recently, Osburne and coworkers [68] described a mutant of P. marinus MED4 exhibiting high resistance to UV stress. By comparing the whole genomes of the mutant and wild type, they could only find a single point mutation, located upstream of a two-gene operon consisting of $p h r A$ (called " $p h r B^{\prime \prime}$ ) and a gene coding for a nudix hydrolase (annotated "MutT", though its specific substrate is not known). This mutation resulted in the constitutive expression of this operon even under non-inductive conditions, suggesting that the occurrence of high levels of DNA photolyase and nudix hydrolase in the cells prior to UV treatment conferred these cells with better 
resistance to this stress than wild type cells, which needed some time to synthesize those proteins. In order to exclude the possibility that the PCC9511 strain used in our experiments possessed the point mutation described by Osburne and co-workers [68], we used the PCR primers defined by authors to amplify this region directly from cells collected from each duplicate culture of the HL and HL+UV experiments. In all cases, the sequences were the same as for the wild type (L. Garzarek and M. Ratin, unpublished data). It is noteworthy that Zinser and co-workers [14], who studied the diel variations of the whole transcriptome of L/D synchronized MED4 cultures, observed a very different expression pattern for $p h r A$ as we did here (Fig. 7A), with an increase at night and a decrease during the day (see [69]). Since they used a moderate light irradiance, reaching only one fourth of our HL conditions at virtual noon (232 vs. $875 \mu \mathrm{mol}$ photons $\mathrm{m}^{-2} \mathrm{~s}^{-1}$ in the present study), it is possible that high PAR conditions are needed to trigger the synthesis of the DNA photolyase.

The $u v r A$ gene showed an expression pattern very similar to that of $p h r A$ in both conditions. It encodes the DNA damage recognition component of the UvrABC system which in bacteria and archaea is involved in the nucleotide excision repair pathway (NER) [70]. This pathway, which has the ability to repair a wide range of structurally unrelated DNA lesions [71], is seemingly fully functional in P. marinus PCC9511, since it possesses conserved homologs of all three subunits of the UvrABC system. In Zinser and coworkers' study [14], uvrA transcript levels showed a rapid increase at the beginning of the light period, remained at quasi steady state during the rest of the day, then decreased at night (see [69]). This indicates that the $u v r A$ system is also activated at moderate light, though it might not need to be adjusted as precisely to the ambient light as under HL.

Another essential safeguard of genomic integrity in prokaryotes is the DNA mismatch repair (MMR) pathway, which removes base mispairings, unpaired bases, and small insertion or deletion loops in DNA by the concerted action of MutS-L-H repair proteins [72]. The genome of $P$. marinus MED4 contains one homolog of mutS, which in E. coli encodes the DNA damage recognition component of the MMR system. Transcript levels of mutS were the lowest at dawn, increased continuously during the light period and decreased at the beginning of the $S$ phase, suggesting that expression of this gene could increase together with the accumulation of $\mathrm{UV}$ and/or reactive oxygen species-induced mutations to DNA. However, no homologs of mutL, encoding an ATPase that forms a complex with MutS once the latter has recognized a DNA lesion, and $m u t H$, coding for a restriction endonuclease that cleaves DNA at GATC sites, can be found in the MED4 genome (and hence PCC9511). The following step of the MMR process, i.e. DNA excision, is ensured in $E$. coli by several genes, including recJ, which encodes a single-stranded DNAspecific exonuclease and the $x s e A B$ operon, which encodes the two subunits of the exodeoxyribonuclease VII [72]. Surprisingly, homologs of these genes can be found in the genomes of the low light-adapted Prochlorococcus ecotypes, but not in high light adapted ecotypes, including MED4 [3]. Thus, even though putative homologs of enzymes involved in DNA resynthesis (the last step of MMR [72]) are present in MED4, including SSB, which has been implicated in the repair of single strand breaks, and several DNA ligases (in addition to the universal, error-free replicative DNA polymerase III, or Pol III, which is also involved in this process), biochemical studies are needed to determine whether MutS is associated with an MMR-like system in HL-adapted $P$. marinus strains or if this system is absent in these organisms.

Expression patterns of the $u m u C$ gene, encoding the subunit $\mathrm{C}$ of the $\mathrm{UmuD}_{2} \mathrm{C}$ error-prone DNA polymerase $\mathrm{V}(\mathrm{Pol} \mathrm{V})$, indicate that DNA translesion synthesis (TLS) reactions, used to bypass lesions in DNA templates on which Pol III usually stalls, occur in PCC9511 [73]. The $u m u C$ gene expression increased during the $\mathrm{G}_{1}$ phase with a peak at noon and was downregulated during the $\mathrm{S}$ phase. Interestingly, in $\mathrm{HL}+\mathrm{UV}$ conditions, its expression level remained high during the entire period of S blockage. Posttranslational activation of Pol V requires the presence of RecA nucleoprotein filaments bound to ssDNA in order to generate its catalytically active form [74]. One can therefore speculate that, even though $u m u C$ expression was upregulated in the middle of the day under $\mathrm{HL}+\mathrm{UV}$ conditions, the transcriptional repression of $\operatorname{rec} A$ during that time may have delayed activation of Pol V. As a result, stalled replication forks may have taken longer to be rescued [75], providing another possible cause for the delay in $\mathrm{S}$ maximum observed under $\mathrm{HL}+\mathrm{UV}$. The $u m u C D$-dependent cell cycle checkpoint model proposed for E. coli [57] may thus be applicable to P. marinus PCC9511.

While the NER (and possibly MMR) pathway is mainly active during the $G_{1}$ phase, Prochlorococcus cells seem to activate another DNA repair system after the initiation of chromosome replication, namely the homologous recombination pathway that acts on double strand breaks. In this process, RuvA and RuvB, form a complex that promotes branch migration of Holliday junctions, then the endonuclease RuvC resolves the Holliday junctions by introducing nicks into DNA strands [76]. The fact that the diel expression pattern of the ruvC gene was similar under $\mathrm{HL}$ or $\mathrm{HL}+\mathrm{UV}$ conditions suggests that the homologous recombination pathway is likely independent of the transcriptional control by the 
LexA/RecA system (see below), as is also the case in the freshwater cyanobacterium Anabaena sp. PCC7120 [77].

\section{Transcriptional regulation of the SOS response by LexA}

The LexA protein of E. coli is a transcriptional repressor of the SOS DNA damage repair response, which is induced upon recognition of DNA damage caused by a wide range of intra- and extracellular elicitors, including UV-irradiation, oxidative stress and DNA replication abnormalities [78]. In PCC9511, the lexA expression pattern was almost the same under $\mathrm{HL}$ and $\mathrm{HL}+\mathrm{UV}$, suggesting that it is oxidative stress rather than UV which is the inducing factor for lexA expression. At a molecular level, de-repression of the fortythree genes constituting the lexA regulon in E. coli [79] is dependent upon the autocatalytic cleavage of the LexA protein, which is stimulated in response to DNA damage by interaction with ssDNA-RecA filaments [37]. This repressor cleavage reaction in E. coli requires several conserved sequence motifs in the LexA repressor, a catalytic serine nucleophile (S119), a basic lysine residue (K156) and an alanine-glycine cleavage bond (A84-G85) [80]. Absence of the LexA nucleophile and cleavage bond, a lack of lexA DNA damage inducibility in Synechocystis sp. PCC6803 [81] and its involvement in carbon fixation led Domain and co-workers [82] to question whether the E. coli type SOS regulon was conserved in cyanobacteria. However, sequence analysis of the LexA protein encoded by $P$. marinus MED4 shows that these three sequence motifs are conserved (see additional file 5: Fig. S4). Furthermore, a search for the LexA binding site in several Prochlorococcus genomes, including MED4 [83], uncovered the consensus motif TAGTACA- $\mathrm{N}_{2}$-TGTACTA upstream of the $r e c A, u m u C$ and $u m u D$ genes as well as $\operatorname{lex} A$ itself, a motif which is similar to the previously described consensus LexA site of gram-positive bacteria [77]. Therefore, unlike Synechocystis sp. PCC6803, it seems that $P$. marinus PCC9511 could well possess a LexA-regulated DNA repair system similar to that in E. coli. The different expression patterns of the LexAcontrolled genes might reflect differences in the sequence conservation of this motif relative to the LexA consensus sequence [84]. Still, the late occurrence during the cell cycle of the lexA gene expression peak and its concomitance with the recA expression maximum in HL conditions is somewhat surprising, given that their products act as repressor and activator of the SOS response, respectively [78] and one might have expected some differential expression patterns. The delay of the recA but not lexA expression peaks in UV-irradiated cells is therefore worth noting in this context as it is more compatible with the expected succession of LexA and RecA regulators in the frame of a typical, coordinated SOS response to DNA damages [37].

Effect of UV on sigma factors and clock gene expression Zinser and coworkers [14] recently showed that the five sigma factors of $P$. marinus MED4 were differentially regulated by light and suggested that this differential phasing, which is in agreement with the idea that they compete for the same core RNA polymerase, contribute to the variety of diel gene expression patterns observed within the whole transcriptome. In order to gain insight into the effects of UV irradiation on the diel RNA accumulation patterns of these expression regulators in PCC9511, we studied the expression of two group II sigma factors (rpoD4 and rpoD8). Their patterns of expression, which are globally consistent with those reported earlier $[14,36]$, suggests that rpoD8 is maximally expressed shortly after dawn and one can hypothesize that its gene product (RpoD8) could control the expression of genes upregulated in the morning (such as $p h r A, u v r A$ and $u m u C$ ). Similarly, rpoD4 RNA levels peak at LDT, and it is possible that RpoD4 could control the expression of genes expressed during this period (such as recA, sepF and lexA). The presence of $\mathrm{UV}$ radiation appeared to affect the expression patterns of both sigma factor genes. For rpoD8, because the daily amplitudes of variation were relatively modest (given that $\mathrm{FC}$ values ranging between -1 and +1 meant that genes were not differentially expressed; see methods), the differences observed during the light period might not be significant. In contrast, for rpoD4, there was a clear decrease in its relative expression at 15:00 in HL $+\mathrm{UV}$ compared to HL conditions, which could potentially result in a delay in the expression of the whole set of genes under the control of this sigma factor.

It has been proposed that the RpoD2 sigma factor of Synechococcus sp. strain PCC7942 is involved in a circadian clock output pathway [85]. There is no direct ortholog of of the rpoD2 gene in MED4 (and hence PCC9511), but one or several of the five sigma factors of this strain might have a similar function. The observed down-regulation of the circadian clock core oscillator kaiB gene at noon under $\mathrm{HL}+\mathrm{UV}$ conditions could result in a modification of the diel expression patterns of one or several of these sigma factors, which in turn modified the expression of genes under their control (see above). Another gene known to convey the circadian clock output signal is sas $A$, which encodes a sensory histidine kinase. Like $k a i B$, it is maximally expressed during the night and its expression dramatically decreased at the beginning of the light period. However, while in HL it recovered its expression just after noon, this recovery took much longer in the presence of UV radiation, which could also potentially 
affect expression of the whole transcriptome. Indeed, SasA plays a key role in chromosome condensation and superhelicity status, which are known to regulate global gene expression and separation of replicated chromosomes [86].

\section{Conclusion}

In this study, we analyzed the response of Prochlorococcus marinus PCC9511 to an environmentally relevant UV stress, provided as a modulated light/dark cycle, as occurs in nature. Our results show that the primary response of UV-irradiated Prochlorococcus cultures involves a shift of chromosome replication phase towards the dark period, potentially minimizing the risk of UV-induced replication errors. Since the genes involved in DNA replication and cell division are most affected by UV stress, this delay of the $\mathrm{S}$ phase is probably related to the strong repression of those genes, in particular dnaA.

Another important outcome of this work is that the strong synchronization of the PCC9511 cells entrained by the modulated light-dark cycle allowed us to observe a clear temporal succession of the expression of genes encoding components of the different DNA repair pathways through the day. The first line of defense is provided by the light-dependent repair of CPDs by the DNA photolyase and removal of damaged oligonucleotides by NER. The presence of a light-regulated mutS gene suggests a possible involvement of MMR during $G_{1}$, but we have no clear evidence yet that a fully operational MMR system exists in PCC9511. At later stages of the L/D cycle, when irradiation levels reached their maxima, $\operatorname{rec} A$ and $\operatorname{lex} A$ expression increase. We hypothesize that the SOS response of PCC9511 is activated later in the afternoon due to LexA inactivation, resulting in the de-repression of genes involved in $\operatorname{rec} A$ mediated HR events (such as ruvC) and DNA repair by the error-prone TLS pathway [87].

In summary, DNA repair pathways appear to operate in a similar way in PCC9511 than in well studied, model organisms such as E. coli or Bacillus subtilis. The signal, if any, that activates the DNA repair pathways in this organism is still unclear, however. If it operates through a photoreceptor, we predict that it involves a visible light sensor rather than a UV sensor. Indeed, there is some evidence for the presence of a blue light photoreceptor in P. marinus MED4 [88]. It must be noted that in the field, UV irradiation is always accompanied by high photon fluxes of visible light, so given its minimalist regulation system, it is quite possible that Prochlorococcus has only one light signalling pathway for both stresses. Alternatively, DNA repair mechanisms could be activated by reactive oxygen species that are produced in response to both stresses [89]. Further biochemical studies are needed to check which of our different hypotheses for the observed delay in S phase is the most likely.

\section{Methods \\ Strain and culture conditions}

The axenic Prochlorococcus marinus strain PCC9511 used in this study has a morphology, pigment content and $16 \mathrm{~S}$ rRNA sequence identical to the fully sequenced strain MED4, a.k.a. CCMP1378 or CCMP1986 [90] and these strains are genetically extremely similar, if not identical. Cultures of PCC9511 were grown at $22 \pm$ $0.5^{\circ} \mathrm{C}$ in $0.2 \mu \mathrm{m}$ filtered PCR-S11 medium [90]. For all experiments using a modulated $12 \mathrm{~h} / 12 \mathrm{~h} \mathrm{~L} / \mathrm{D}$ cycle, we used a custom-designed, computer-controlled illumination system (hereafter called 'cyclostat'), a modification of a previously described system [91] with an UV module added. PAR was provided by two symmetrical banks of 8 dimmable, U-shaped Philips PL-L 90 daylight fluorescence tubes (Philips Lightning, Eindhoven, NL) located on each side of the $50 \mathrm{~L}$ glass tank containing the culture flasks, whereas UV radiation was supplied by five pairs of UVA-340 fluorescent tubes (Q-Panel Lab products, Westlake, OH, USA) located above the cultures. PAR level was adjusted to reach a midday maximum of $100 \mu \mathrm{mol}$ photons $\mathrm{m}^{-2} \mathrm{~s}^{-1}$ for LL conditions and $900 \mu \mathrm{mol}$ photons $\mathrm{m}^{-2} \mathrm{~s}^{-1}$ for $\mathrm{HL}$ conditions. For long or short term UV experiments, HL conditions were supplemented by a $12 \mathrm{~h} / 12 \mathrm{~h} \mathrm{~L} / \mathrm{D}$ cycle of UV radiation reaching $7.59 \mathrm{~W} \mathrm{~m}^{-2} \mathrm{UVA}(320-400 \mathrm{~nm})$ and $0.57 \mathrm{~W}$ $\mathrm{m}^{-2}$ UVB (280-320 $\mathrm{nm}$ ) at virtual noon (see additional file 1: Fig. S1).

For preliminary growth experiments, replicate $600 \mathrm{~mL}$ batch cultures were maintained in 1L Erlenmeyer glass flasks (Schott Duran, Mainz, Germany) for HL only experiments or $1 \mathrm{~L}$ Erlenmeyer quartz flasks (Atelier Jean Premont, Bordeaux, France) for HL+UV experiments. For transcriptomic analyses, two $7 \mathrm{~L}$ replicate cultures were kept in exponential growth phase at cell densities of around $10^{8}$ cells $\mathrm{mL}^{-1}$ by continuous dilution with fresh medium, at a rate adjusted to population growth (e.g., $4.83 \mathrm{~L}$ must be added per day to a $7 \mathrm{~L}$ culture growing at one division per day). For these largescale experiments, we used custom-made, cylindrical $8 \mathrm{~L}$ quartz flasks (Ellipse, La Chapelle-la-Reine, France). All cultures were acclimated to experimental light conditions at least two weeks before the start of sampling. For long-term HL+UV conditions, cultures were slowly acclimated by incrementally increasing the UV dose by ca. $2 \mathrm{~W} \mathrm{~m}^{-2}$ steps with at least 2-3 days of acclimation at each step. To further reduce UV stress, the pre-cultures were diluted daily at dawn and maintained at a cell density higher than $5 \times 10^{5}$ cells $\mathrm{ml}^{-1}$. To check for the eventual occurrence of self shading, we analyzed the 
timing of the $S$ phase peak and the percentage of cells in $\mathrm{S}$ in the peak in samples collected at different depths of the quarz flask (i.e. different distances from UV lamps) and observed that there were no significant differences (data not shown).

\section{Growth and cell cycle analyses by flow cytometry}

Culture samples for cell density measurements and cell cycle analyses were taken automatically at $1 \mathrm{~h}$ intervals using an electronic peristaltic pump (Masterflex Cartridge Pump 8; Fisher Bioblock Scientific, Illkirch, France) fitted to a custom-designed fraction collector. Aliquots were kept at $4{ }^{\circ} \mathrm{C}$ in the dark and fixation of cells was done within a maximum timeframe of $9 \mathrm{~h}$ after sampling, a delay shown to cause only negligible changes on the DNA content in Prochlorococcus cells [92]. 400 microliter aliquots were fixed in glutaraldehyde (0.25\% final concentration; Sigma Aldrich, Saint-Louis, $\mathrm{MO}$, USA), incubated for $10 \mathrm{~min}$ at $4^{\circ} \mathrm{C}$ in the dark, frozen in liquid nitrogen and stored at $-80^{\circ} \mathrm{C}$. Frozen samples were thawed at room temperature (RT), then diluted in TE buffer ( $\mathrm{pH}$ 9) (Tris $\mathrm{HCl} 10 \mathrm{mM}$, EDTA 1 $\mathrm{mM})$ and cell concentrations were analyzed in the presence of $0.95 \mu \mathrm{m}$ fluorescent microspheres (Polysciences, Warrington, PA, USA) which were used as internal references as previously described [93]. For cell cycle analyses, diluted samples were first stained with SYBR Green I (Invitrogen Molecular Probes, Carlsbad, CA, USA), used at a final concentration of $10^{-4}$ of the commercial stock solution, as described [94]. Samples were analyzed either on a BD FACS Aria or a BD FACS Canto flow cytometer (Becton Dickinson Biosciences, San Jose, CA, USA), both equipped with a blue (488 $\mathrm{nm}$ ) excitation laser. Cell count data files were analysed using the CytoWin 4.31 software [95] (available at http://www.sb-roscoff.fr/Phyto/) and cell cycle data files using the MultiCycle 4.0 software suite (Phoenix Flow Systems, San Diego, CA, USA). The duration of particular cell cycle phases was estimated based on the equations of Carpenter and Chang [30]. For batch cultures, division rates per day were computed from cell number variations using: $\mu_{\mathrm{nb}}=\frac{\operatorname{Ln}\left(N\left(t_{2}\right) / N\left(t_{1}\right)\right)}{\left(t_{2}-t_{1}\right)}$; where $\mu_{\mathrm{nb}}$ is the estimated growth rate $\left(\mathrm{d}^{-1}\right)$ and $N(t)$ is the average cell concentration of two duplicate cultures at time points $t_{2}$ and $t_{1}$ taken at a $24 \mathrm{~h}$ interval, in a period when no division occurred, e.g. early morning when most cells were in $G_{1}$ phase. For continuous cultures, division rates were estimated from cell cycle data using the formula of Carpenter and Chang [30]: $\mu_{\mathrm{cc}}=\frac{\sum_{i=1}^{n} \ln \left[1+f_{\mathrm{S}}\left(t_{\mathrm{i}}\right)+f_{\mathrm{G} 2}\left(t_{\mathrm{i}}\right)\right]}{n+\left(T_{\mathrm{S}}+T_{\mathrm{G} 2}\right)} \times 24$

where $\mu_{\mathrm{cc}}$ is the estimated growth rate $\left(\mathrm{d}^{-1}\right), n$ is the number of samples collected at fixed intervals during one diurnal cycle, $f_{S}\left(t_{\mathrm{i}}\right)$ and $f_{G 2}\left(t_{\mathrm{i}}\right)$ are the fractions of cells in $\mathrm{S}$ and $\mathrm{G}_{2}$ phases at time $t_{\mathrm{i}}, T_{\mathrm{S}}+T_{\mathrm{G} 2}(\mathrm{~h})$ is the sum of $\mathrm{S}$ and $\mathrm{G}_{2}$ phases durations, computed as twice the delay $(\Delta t)$ between the peaks of cells in these phases $\left[2 \times\left(t_{\mathrm{G} 2 \max }-t_{\mathrm{Smax}}\right)\right]$.

\section{RNA sampling and extraction}

For transcriptomic analyses, cultures were sampled by pumping $400 \mathrm{~mL}$ aliquots into $1 \mathrm{~L}$ glass Erlenmeyer flasks eight times per L/D cycle during three consecutive days, with a shortened sampling interval around the expected $S$ phase period, i.e. at 06:00, 09:00, 12:00, 15:00, 18:00, 20:00, 22:00 and 02:00. Immediately after harvesting, samples were chilled by swirling into liquid nitrogen for about $30 \mathrm{~s}$ (so that their temperature rapidly dropped down to ca. $4^{\circ} \mathrm{C}$ ) and transferred into pre-chilled $450 \mathrm{~mL}$ polycarbonate centrifuge buckets (Beckman Coulter, Fullerton, CA, USA) containing a Pluronic F68 solution $(0.005 \%$ final concentration; Sigma Aldrich). Samples were then harvested by centrifugation at $17,700 \times \mathrm{g}$ for $7 \mathrm{~min}$ at $4^{\circ} \mathrm{C}$ followed by a second centrifugation in microtubes $(1.5 \mathrm{~min}$ at $\mathrm{RT}$ and $16,100 \times \mathrm{g}$ ). Cell pellets were finally re-suspended in $500 \mu \mathrm{l}$ Trizol (Invitrogen, Carlsbad, CA, USA), frozen in liquid nitrogen and kept at $-80^{\circ} \mathrm{C}$. During all transfer steps, samples were kept on ice in the dark. The total workflow from sampling to freezing the samples took no longer than $18 \mathrm{~min}$.

RNA extractions were performed mainly as described in [45] except that the miRNeasy kit was used (as recommended by the manufacturers; Qiagen, Valencia, CA, USA) instead of the RNeasy protocol (after Trizol extraction), in order to recover both large and small RNAs. Two successive DNase treatments were performed on the columns using the Qiagen RNase-free DNase Set (Qiagen), followed by elution from the column in $30 \mathrm{ml}$ DEPC-treated water. RNA samples were precisely quantified using a NanoDrop 1000 spectrophotometer (Thermo Scientific, Wilmington, DE, USA), quality-controlled with a BioAnalyzer 2100 using the RNA 6000 Nano Kit (Agilent, Santa Clara, CA, USA) and the absence of significant DNA contamination was confirmed by qPCR. All RNA samples were frozen in liquid nitrogen and stored at $-80^{\circ} \mathrm{C}$.

\section{Quantitative PCR analyses}

Real time qPCR analyses were carried out on a DNA Engine/Chromo4 Real Time PCR-Detector (BioRad, Hercules, CA, USA) and using absolute SYBR Green ROX Mix (Abgene, Epsom, UK), as previously described [47] but starting from 50 ng of each RNA sample and using $250 \mathrm{nM}$ of each primer. Primers used in this study, which were designed using Primer-Express 
software (v2.0; Applied Biosystems, Foster City, CA, USA), are listed in Table 4. All reactions were performed in duplicate. Resulting data were analysed using the comparative CT $(\Delta \Delta \mathrm{CT})$ method as described in the Applied Biosystems user bulletin \#2 [96] using the $r n p B$ gene as an internal standard [27] to normalize the transcript levels from all time points and light conditions to the HL 06:00 time point, which was used as a reference.

\section{DNA microarray analyses}

Microarray analyses were performed for time points 15:00, 18:00, 20:00 and 22:00 in HL and HL+UV conditions for two L/D cycles and two culture replicates, resulting in a total of 4 biological replicates per time point and light condition. All microarray expression analyses described in this study were performed using a P. marinus MED4 whole genome 4-Plex tiling microarray (Roche NimbleGen, Madison, WI, USA) carrying 4 $\times 60,053$ probes with average size of 50 nucleotides (assuming that the genome of P. marinus PCC9511 is identical to that of MED4). cDNA labeling and hybridization steps were performed as recommended by the manufacturer [97]. Briefly, cDNA was synthesized from $10 \mu \mathrm{g}$ of total RNA using the SuperScript ${ }^{\mathrm{tm}}$ DoubleStranded cDNA Synthesis kit (Invitrogen, Carlsbad, CA, USA) followed by cDNA labeling of $1 \mu \mathrm{g}$ of double stranded cDNA using 5'-Cy3- or 5'-Cy5-labeled random primers (TriLink Technologies, San Diego, CA, USA). cDNA amplification and labeling efficiency was checked using the NanoDrop ND-1000 spectrophotometer, a minimum of a 10 -fold cDNA increase being considered necessary for further use of the sample. Subsequent hybridization of labeled cDNA ( $2 \mu \mathrm{g}$ of each labeled cDNA diluted in Nimblegen hybridization solution) to the NimbleGen array was performed overnight $(16 \mathrm{~h}$ at $42^{\circ} \mathrm{C}$ in the dark) using the NimbleGen Hybridization System. Array slides were washed and dried using NimbleGen Wash Buffer kit, followed by scanning using the GenePix Personal 4100A scanner (Molecular Devices, Sunnyvale, CA, USA) at $5 \mu \mathrm{m}$ resolution. The NimbleScan v2.6 software suite [98] was then used to extract the raw probe signal intensities for both $\mathrm{Cy} 3$ and $\mathrm{Cy} 5$ channels from the array TIFF images. In order to maximize the number of spots with a significant signal to background ratio, the reference sample hybridized on all arrays corresponded to a RNA pool of all samples of one complete day harvested in both light conditions and at all stages under investigation (all time points, cultures $\mathrm{A}$ and $\mathrm{B}, \mathrm{HL}$ and UV conditions). Furthermore, replicate samples from the two examined L/D cycles (the same time point and light condition) were systematically hybridized in dye switch experiments in order to minimize bias due to differential dye bleaching or unequal incorporation of the $\mathrm{Cy} 3$ and $\mathrm{Cy} 5$ dyes during cDNA labeling reactions.

All microarray experiments were MIAME compliant and raw data were deposited under experiment name PCC9511-15-18-20-22 and accession number E-TABM-

Table 4 Primer sets used for qPCR analyses of the diel cycle of expression of selected genes from Prochlorococcus marinus PCC9511

\begin{tabular}{|c|c|c|c|}
\hline Locus tag & Gene & Forward Primer & Reverse Primer \\
\hline RNA_42 & $r n p B$ & 64-AAGTCCGGGCTCCCATATG & 135-TGTGGCACTATCCTCACGGTTA \\
\hline PMM0285 & phra & 1000-GGAGAGACCGGAGTACCTATAGTTGA & 1088-GCGACTATCATCCTACATCTATTATGCA \\
\hline PMM0395 & sepF & 397-GAAAGAGTCGGTGAAAGCATTITा & 470-GCCTCCTCTGGGAAAGAACTAGT \\
\hline PMM0565 & $d n a A$ & 492-TGGTGTCGGTCTTGGAAAGAC & 568-CTTTCGCATCTGGATCAATTTCT \\
\hline PMM0937 & umuC & 762-TCAAGTAAGTAGAAGCTITGGAAAACC & 889-TAGTAATGGCAGATGATTTTAAGCTTTG \\
\hline PMM1054 & ruvC & 331-GCAGGCTCTGGCAAAGCA & 407-TTTGGTGCACGGGTTAAATTT \\
\hline PMM1077 & sas $A$ & 430-CTTTTAAGAATGGTTGCACATGAATT & 511-TTTGTCCTAGTTITTGACTTTGAATAGC \\
\hline PMM1262 & lexA & 227-AGATCTTTGAGGGAGTCCCAATT & 299-TGGAGGTCGGAAAATGTTTCA \\
\hline PMM1309 & $\mathrm{fts} Z$ & 415-GGGATAGTAACCAAGCCATTTTCA & 494-TCTGCTAATCTTGCAATCCCTTCT \\
\hline PMM1342 & kaic & 666-AGGAACCGTACATATGAAAGGAGAA & 746-CTCATCGCTCCTAAGGCAAAA \\
\hline PMM1343 & kaiB & 142-AAACAACCTCAACTTGCTGAAGAA & 193-TAACAGGAGGAGGTAAAATCTITGC \\
\hline PMM1452 & $a t p D$ & 435-AATCGACCCATCCCTCATTG & 512-ATTTGAGAGGCAAGACTAGCATCA \\
\hline PMM1455 & $\operatorname{atpH}$ & 68-GCCCGGGCCTTGGA & 129-AGGTTGGCGGGCAATACC \\
\hline PMM1562 & recA & 319-GCTGAACATGCTITAGATCCAGTCT & 398-GTATCTGGCTGCGAAACTAGTAAATTT \\
\hline PMM1629 & rpoD8 & 726-CAAAGCTGGGCAGCCAGTA & 820-CAGTCCATTTCGATTTGCTCATC \\
\hline PMM1645 & muts & 2281-ACAAGAATTGGAGCCGTAGATGA & 2366-TGATTTAGTATTGATGCTGTTTCTGACA \\
\hline PMM1697 & rpoD4 & 746-CTCAAAGTGCTCCATGCGC & 848-GATTGTTCTATCCATCCCTTCCA \\
\hline PMM1712 & uvrA & 2775-GATAATTGATCTTGGACCTGATGGA & 2865-ACTTATTGGATGCTTCGCAACA \\
\hline
\end{tabular}

The locus tag of the corresponding genes in $P$. marinus MED4 are indicated 
1028 at the ArrayExpress database of the EMBL-EBI (http://www.ebi.ac.uk/microarray-as/ae/).

\section{Statistical Analyses of microarrays}

Statistical analyses were done using custom-designed scripts written under the $R$ environment [99]. The probe dataset used in this study covered 1,968 probes out of the 2,014 genes identified so far in the MED4 genome $[23,28]$. The missing genes (see additional file 6: Table T2) corresponded to two probe categories that were systematically removed from the analysis. These probes were either to highly conserved multiple copy genes for which it was not possible to design specific probes (e.g. for some hli genes) or to very short ORFs for which the only designed probes were overlapping another gene or intergenic areas. The functional category of each gene was assigned using the Cyanobase database [100].

Microarray background bias was removed using the robust multi-chip average (RMA) background subtraction algorithm [101] from the preprocess Core R package implemented Bioconductor, an open source and open development software project [102]. This step was followed by normalization of the Cy3 and Cy5 signal intensities within arrays by loess normalization as well as between arrays by applying a quantile normalization, implemented in the R package LIMMA [103]. Data summarization of preprocessed probe sets covering individual genes was done by using the median polishing algorithm from the stats $\mathrm{R}$ package [99]. Student's t-test and the linear modeling features and empirical Bayes test statistics of the LIMMA package [104] were used to perform pairwise comparison of the different light conditions at the same time point (i.e. UV15 vs. HL15, UV18 vs. HL18, UV20 vs. HL20, UV22 vs. HL22) as well as comparing the $\mathrm{S}$ phase maximum under HL and UV (i.e. UV20 vs. HL18). Variance between all data points was also analyzed using one way ANOVA analysis and two way ANOVA analysis (TFA) where "light" and "time" were chosen to create suitable groups $[105,106]$. Since multiple tests were performed, statistical significance was adjusted based on the Benjamini and Hochberg algorithm [107] to control the FDR at $1 \%$. Finally, to investigate the technical and biological reproducibility of our results, hierarchical clustering analyses [108] was performed with the hclust function from the stats $\mathrm{R}$ package [99] using the clustering method "average" and a Pearson correlation on a subset of differentially expressed genes selected based on the statistical significance of their differential expression as determined by one way ANOVA (FDR $\leq 0.1)$.

\section{Additional material}

\begin{abstract}
Additional file 1: Figure S1. Diel cycle of visible and UV radiations, as measured in the cyclostat growth chamber. The different plots correspond to the photosynthetically active radiation [PAR; $E_{\max }(400-700$ $\mathrm{nm})=875 \mu \mathrm{mol}$ photons $\mathrm{m}^{-2} \mathrm{~s}^{-1}$; red line], the total UV radiation [ $E_{\max }$ $(280-400 \mathrm{~nm})=8.22 \mathrm{~W} \mathrm{~m}^{-2}$; green line], the UV-A radiation $\left[\mathrm{E}_{\max }(320-400\right.$ $\mathrm{nm})=7.59 \mathrm{~W} \mathrm{~m}^{-2}$; yellow line] and the UV-B radiation $\left[E_{\max }(280-320 \mathrm{~nm})\right.$ $=0.57 \mathrm{~W} \mathrm{~m}^{-2}$; violet line] components. When only visible light neon tubes were switched on, UV radiation levels were near detection limits $\left[E_{\max }(280-400 \mathrm{~nm})=0.04 \mathrm{~W} \mathrm{~m}^{-2}\right.$; data not shown].
\end{abstract}

Additional file 2: Figure S2. Examples of flow cytograms and cell cycle analyses of Prochlorococcus marinus PCC9511 cells grown under $\mathrm{HL}$ and sampled at different times of the L/D cycle. A, dot plot of green fluorescence from DNA vs. side scatter, for a culture sample taken during the $G_{1}$ phase, stained with the DNA dye SYBR Green I, then analyzed by flow cytometry. B, FL1 histogram of the same sample as in Fig. A, showing the DNA frequency distribution of Prochlorococcus cells, from which the proportions of cells in $G_{1}, S$ and $G_{2}$ phases were calculated using the MultiCycle $A V^{\mathrm{TM}}$ software. $\mathbf{C}$, same as graph $\mathrm{A}$, but for a culture sample taken during the $\mathbf{S}$ phase. $\mathbf{D}$, same as graph $\mathbf{B}$ for the sample used to draw graph $\mathbf{C}$. E, same as graph A, but for a culture sample taken during the $G_{2}$ phase. $\mathbf{F}$, same as graph $B$ for the sample used to draw graph $\mathrm{E}$.

Additional file 3: Table T1. Complete set of gene expression data as measured by microarray analyses. This table includes locus tags, gene names, product description as well as cyanobase functional categories and sub-categories for all 1,963 genes present on the PCC9511 array. Expression data are shown as $\log _{2}(F C)$ calculated for each experimental sample (blue background) as well as for the 5 pairwise comparisons performed in this study (UV15 vs. HL15, UV18 vs. HL18, UV20 Vs. HL18, UV20 vs. HL20 and UV22 vs. HL22; green background). For the latter, pvalues and adjusted $p$-values were calculated using LIMMA and t-test (beige background). Values highlighted in red correspond to genes and pairwise comparisons for which adjusted p-values (FDR) was $\leq 0.1$ and $\log _{2}(F C)>1$. This subset of genes corresponds to the one used to build Fig. 4. The last columns show $p$-values and adjusted $p$-values calculated with one-way and two-way ANOVA where group 1 corresponds to light treatment and group 2 to "sampling time" (purple background).

Additional file 4: Figure S3. Patterns of atpD and atpH gene expression of L/D-synchronized Prochlorococcus marinus PCC9511 cultures under $\mathrm{HL}$ and UV growth conditions, as measured by qPCR. The percentage of cells in the $S$ phase of the cell cycle under $\mathrm{HL}$ (solid line) and HL+UV (dashed line) are also shown for comparison. Error bars indicate mean deviation for two biological replicates. Grey and black bars indicate light and dark periods.

Additional file 5: Figure S4. Sequence alignment of LexA homologs. LexA protein sequences from Prochlorococcus marinus MED4 (PMM1262), Synechococcus sp. WH7803 (SynWH7803_1680) and Synechocystis sp. PCC6803 (SII1626) were aligned against the Escherichia coli K12 LexA sequence (B4043). The DNA binding domain, preventing expression of DNA repair proteins (blue frame) and the peptidase S24-like domain, catalyzing self-cleavage of LexA (green frame) are indicated as well as conserved bases involved in the LexA repressor cleavage reaction (A84G85 cleavage bond, S119 nucleophile, basic K156; red frame; [80]. Sequence alignments were made with BioEdit using ClustalW.

Additional file 6: Table T2. Subset of P. marinus PCC9511 genes not included in microarray analyses.

\section{Acknowledgements}

We thank Dr. Antoine Sciandra for providing a preliminary version of the cyclostat software and M. Cédric Prevost for adapting it to our custom experimental set up. Dr. John Kenneth Colbourne and Jacqueline Ann Lopez are acknowledged for their help with microarray experiments as well as Dr. 
Simon Dittami and M. Animesh Shukla for discussion about statistical analyses. CK received a Marie Curie grant from EU (Esteam PhD program)

\section{Author details}

'UPMC-Université Paris 06, Station Biologique, Place Georges Teissier, 29680 Roscoff, France. ${ }^{2}$ CNRS, UMR 7144, Groupe Plancton Océanique, 29680 Roscoff, France. ${ }^{3}$ CNRS, FR 2424, Service Informatique et Génomique, 29680 Roscoff, France. ${ }^{4}$ Clermont Université, Université Blaise Pascal, UMR CNRS 6023, Laboratoire Microorganismes: Génome et Environnement, BP 10448 , 63000 Clermont-Ferrand, France. ${ }^{5}$ CEMAGREF, UR Biologie des Ecosystèmes Aquatiques, Laboratoire d'Hydroécologie Quantitative, 3 bis quai Chauveau, CP 220, 69336 Lyon Cedex 09, France. 'Department of Biology, 1001 East Third Street, Indiana University, Bloomington, IN 47405, USA.

\section{Authors' contributions}

$L G, F P, D K$ and $C K$ conceived the experiments. CK, FP, DMF, CB, NB, XL, PG and LG participated in sampling. CK did the flow cytometry measurements and cell cycle analyses. CK and MR extracted RNA samples and performed the microarrays and $\mathrm{qPCR}$ analyses. $L G, G L C$ and MF wrote scripts in $R$ to analyze microarrays and CK and MR participated in these analyses. JFL, LG and FP conceived and/or built the UV-visible cyclostat. CK, FP, DK and LG wrote the paper. All authors read and approved the final manuscript.

Received: 8 May 2010 Accepted: 29 July 2010 Published: 29 July 2010

\section{References}

1. Chisholm SW, Olson RJ, Zettler ER, Goericke R, Waterbury JB, Welschmeyer NA: A novel free-living prochlorophyte abundant in the oceanic euphotic zone. Nature 1988, 334:340-343.

2. Coleman ML, Chisholm SW: Code and context: Prochlorococcus as a model for cross-scale biology. Trends Microbiol 2007, 15:398-407.

3. Partensky F, Garczarek L: Prochlorococcus: Advantages and limits of minimalism. Ann Rev Mar Sci 2010, 2:211-237.

4. Scanlan DJ, Ostrowski M, Mazard S, Dufresne A, Garczarek L, Hess WR, Post AF, Hagemann M, Paulsen I, Partensky F: Ecological genomics of marine picocyanobacteria. Microbiol Mol Biol Rev 2009, 73:249-299.

5. Asato $Y$ : Toward an understanding of cell growth and the cell division cycle of unicellular photoautotrophic cyanobacteria. Cell Mol Life Sci 2003, 60:663-687.

6. Jacquet S, Partensky F, Marie D, Casotti R, Vaulot D: Cell cycle regulation by light in Prochlorococcus strains. Appl Environ Microbiol 2001, 67:782-790

7. Vaulot D, Marie D, Olson RJ, Chisholm SW: Growth of Prochlorococcus, a photosynthetic prokaryote, in the equatorial Pacific Ocean. Science 1995, 268:1480-1482.

8. Shalapyonok A, Olson RJ, Shalapyonok LS: Ultradian growth in Prochlorococcus spp. Appl Environ Microbiol 1998, 64:1066-1069.

9. Claustre H, Bricaud A, Babin M, Bruyant F, Guillou L, Le Gall F, Marie D, Partensky F: Diel variations in Prochlorococcus optical properties. Limnol Oceanogr 2002, 47:1637-1647.

10. Bruyant F, Babin M, Genty B, Prasil O, Behrenfeld MJ, Claustre H, Bricaud A, Garczarek L, Holtzendorff J, Koblizek M, et al: Diel variations in the photosynthetic parameters of Prochlorococcus strain PCC 9511: Combined effects of light and cell cycle. Limnol Oceanogr 2005, 50:850-863.

11. Mary I, Garczarek L, Tarran GA, Kolowrat C, Terry MJ, Scanlan DJ, Burkill PH, Zubkov MV: Diel rhythmicity in amino acid uptake by Prochlorococcus. Environ Microbiol 2008, 10:2124-2131.

12. Garczarek L, Partensky F, Irlbacher H, Holtzendorff J, Babin M, Mary I, Thomas JC, Hess WR: Differential expression of antenna and core genes in Prochlorococcus PCC 9511 (Oxyphotobacteria) grown under a modulated light-dark cycle. Environ Microbiol 2001, 3:168-175.

13. Holtzendorff J, Partensky F, Jacquet S, Bruyant F, Marie D, Garczarek L, Mary I, Vaulot D, Hess WR: Diel expression of cell cycle-related genes in synchronized cultures of Prochlorococcus sp. strain PCC9511. J Bacteriol 2001, 183:915-920.

14. Zinser ER, Lindell D, Johnson Zl, Futschik ME, Steglich C, Coleman ML, Wright MA, Rector T, Steen R, McNulty N, et al: Choreography of the transcriptome, photophysiology, and cell cycle of a minimal photoautotroph, Prochlorococcus. PLOS ONE 2009, 4:e5135.

15. Partensky F, Hess WR, Vaulot D: Prochlorococcus, a marine photosynthetic prokaryote of global significance. Microbiol Mol Biol Rev 1999, 63:106-127.
16. Campbell $L$, Vaulot D: Photosynthetic picoplankton community structure in the subtropical North Pacific Ocean near Hawaii (station ALOHA). Deep Sea Res 1993, 40:2043-2060.

17. Moore LR, Chisholm SW: Photophysiology of the marine cyanobacterium Prochlorococcus: Ecotypic differences among cultured isolates. Limnol Oceanogr 1999, 44:628-638.

18. Moore LR, Rocap G, Chisholm SW: Physiology and molecular phylogeny of coexisting Prochlorococcus ecotypes. Nature 1998, 393:464-467.

19. Johnson ZI, Zinser ER, Coe A, McNulty NP, Woodward EM, Chisholm SW: Niche partitioning among Prochlorococcus ecotypes along ocean-scale environmental gradients. Science 2006, 311:1737-1740.

20. West NJ, Schonhuber WA, Fuller NJ, Amann RI, Rippka R, Post AF, Scanlan DJ: Closely related Prochlorococcus genotypes show remarkably different depth distributions in two oceanic regions as revealed by in situ hybridization using $16 \mathrm{~S}$ rRNA-targeted oligonucleotides. Microbiology 2001, 147:1731-1744.

21. Zinser ER, Johnson ZI, Coe A, Karaca E, Veneziano D, Chisholm SW: Influence of light and temperature on Prochlorococcus ecotype distributions in the Atlantic Ocean. Limnol Oceanogr 2007, 52:2205-2220.

22. Malmstrom RR, Coe A, Kettler GC, Martiny AC, Frias-Lopez J, Zinser ER, Chisholm SW: Temporal dynamics of Prochlorococcus ecotypes in the Atlantic and Pacific oceans. ISME J 2010.

23. Kettler GC, Martiny AC, Huang K, Zucker J, Coleman ML, Rodrigue S, Chen F, Lapidus A, Ferriera S, Johnson J, et al: Patterns and implications of gene gain and loss in the evolution of Prochlorococcus. PLoS Genet 2007, 3:2515-2528

24. Rocap G, Larimer FW, Lamerdin J, Malfatti S, Chain P, Ahlgren NA, Arellano A, Coleman M, Hauser L, Hess WR, et al: Genome divergence in two Prochlorococcus ecotypes reflects oceanic niche differentiation. Nature 2003, 424:1042-1047.

25. Dufresne A, Salanoubat M, Partensky F, Artiguenave F, Axmann IM, Barbe V, Duprat S, Galperin MY, Koonin EV, Le Gall F, et al: Genome sequence of the cyanobacterium Prochlorococcus marinus SS120, a nearly minimal oxyphototrophic genome. Proc Natl Acad Sci USA 2003, 100:10020-10025.

26. Ashby MK, Houmard J: Cyanobacterial two-component proteins: Structure, diversity, distribution, and evolution. Microbiol Mol Biol Rev 2006, 70:472-509.

27. Mary I, Vaulot D: Two-component systems in Prochlorococcus MED4: Genomic analysis and differential expression under stress. FEMS Microbiol Lett 2003, 226:135-144.

28. Steglich C, Futschik ME, Lindell D, Voss B, Chisholm SW, Hess WR: The challenge of regulation in a minimal photoautotroph: non-coding RNAs in Prochlorococcus. PLoS Genet 2008, 4:1-14.

29. Cooper S, Helmstetter CE: Chromosome replication and the division cycle of Escherichia coli B/r. J Mol Biol 1968, 31:519-540.

30. Carpenter EJ, Chang J: Species-specific phytoplankton growth-rates via diel DNA-synthesis cycles. I. Concept of the method. Mar Ecol Prog Ser 1988, 43:105-111.

31. Komenda J, Knoppova J, Krynicka V, Nixon PJ, Tichy M: Role of FtsH2 in the repair of Photosystem II in mutants of the cyanobacterium Synechocystis PCC 6803 with impaired assembly or stability of the CaMn (4) cluster. Biochim Biophys Acta 2010, 1797:566-575.

32. Marbouty M, Saguez C, Cassier-Chauvat C, Chauvat F: Characterization of the FtsZ-interacting septal proteins SepF and Ftn6 in the sphericalcelled cyanobacterium Synechocystis strain PCC6803. J Bacteriol 2009, 191:6178-6185.

33. Beuning PJ, Simon SM, Godoy VG, Jarosz DF, Walker GC: Characterization of Escherichia coli translesion synthesis polymerases and their accessory factors. Methods Enzymol 2006, 408:318-340.

34. Osanai T, Ikeuchi M, Tanaka K: Group 2 sigma factors in cyanobacteria. Physiol Plant 2008, 133:490-506.

35. Imamura S, Asayama M: Sigma factors for cyanobacterial transcription. Gene Regul Syst Biol 2009, 3:65-87.

36. Holtzendorff J, Partensky F, Mella D, Lennon JF, Hess WR, Garczarek L: Genome streamlining results in loss of robustness of the circadian clock in the marine cyanobacterium Prochlorococcus marinus PCC 9511. J Biol Rhythms 2008, 23:187-199.

37. Butala M, Zgur-Bertok D, Busby SJW: The bacterial LexA transcriptional repressor. Cell Mol Life Sci 2009, 66:82-93.

38. Golden SS: Timekeeping in bacteria: the cyanobacterial circadian clock. Curr Opin Microbiol 2003, 6:535-540. 
39. Llabres M, Agusti S: Picophytoplankton cell death induced by UV radiation: Evidence for oceanic Atlantic communities. Limnol Oceanogr 2006, 51:21-29.

40. Sommaruga R, Hofer JS, Alonso Saez L, Gasol JA: Differential sunlight sensitivity of picophytoplankton from surface Mediterranean coastal waters. Appl Environ Microbiol 2005, 71:2154-2157.

41. Dufresne A, Garczarek L, Partensky F: Accelerated evolution associated with genome reduction in a free-living prokaryote. Genome Biol 2005, 6 R14.

42. Binder BJ, Chisholm SW, Olson RJ, Frankel SL, Worden AZ: Dynamics of picophytoplankton, ultraphytoplankton and bacteria in the central equatorial Pacific. Deep Sea Res II 1996, 43:907-931.

43. Liu H, Campbell L, Landry MR, Nolla HA, Brown SL, Constantinou J: Prochlorococcus and Synechococcus growth rates and contributions to production in the Arabian Sea during the 1995 Southwest and Northeast monsoons. Deep Sea Res II 1998, 45:2327-2352.

44. Liu HB, Nolla HA, Campbell L: Prochlorococcus growth rate and contribution to primary production in the equatorial and subtropical North Pacific Ocean. Aquat Microb Ecol 1997, 12:39-47.

45. Garczarek L, Dufresne A, Blot N, Cockshutt AM, Peyrat A, Campbell DA Joubin $L$, Six $C$ : Function and evolution of the $p s b A$ gene family in marine Synechococcus: Synechococcus sp. WH7803 as a case study. ISME J 2008, 2:937-953.

46. Huang LX, McCluskey MP, Ni H, LaRossa RA: Global gene expression profiles of the cyanobacterium Synechocystis sp. strain PCC6803 in response to irradiation with UV-B and white light. J Bacterio/ 2002, 184:6845-6858

47. Six C, Joubin L, Partensky F, Holtzendorff J, Garczarek L: UV-induced phycobilisome dismantling in the marine picocyanobacterium Synechococcus sp. WH8102. Photosynth Res 2007, 92:75-86

48. Ehling-Schulz M, Schulz S, Wait R, Gorg A, Scherer S: The UV-B stimulon of the terrestrial cyanobacterium Nostoc commune comprises early shock proteins and late acclimation proteins. Mol Microbiol 2002, 46:827-843.

49. Gao Y, Xiong W, Li XB, Gao CF, Zhang YL, Li H, Wu QY: Identification of the proteomic changes in Synechocystis sp. PCC 6803 following prolonged UV-B irradiation. J Exp Bot 2009, 60:1141-1154.

50. Shadan FF: Circadian tempo: a paradigm for genome stability? Med Hypotheses 2007, 68:883-891.

51. Ross C, Santiago-Vazquez $L$, Paul V: Toxin release in response to oxidative stress and programmed cell death in the cyanobacterium Microcystis aeruginosa. Aquat Toxicol 2006, 78:66-73.

52. Ning SB, Guo HL, Wang L, Song YC: Salt stress induces programmed cell death in prokaryotic organism Anabaena. J Appl Microbiol 2002, 93:15-28.

53. Singh SP, Hader DP, Sinha RP: Cyanobacteria and ultraviolet radiation (UVR) stress: Mitigation strategies. Ageing Res Rev 2009, 9:79-90.

54. Moore LR, Coe A, Zinser ER: Culturing the marine cyanobacterium Prochlorococcus. Limnol Oceanogr Meth 2007, 5:353-362.

55. Elledge S: Cell cycle checkpoints: preventing an identity crisis. Science 1996, 274:1664-1672

56. Helmstetter CE, Pierucci O: Cell division during inhibition of deoxyribonucleic acid synthesis in Escherichia coli. J Bacteriol 1968, 95:1627-1633.

57. Opperman T, Murli S, Smith BT, Walker GC: A model for a umuDCdependent prokaryotic DNA damage checkpoint. Proc Natl Acad Sci USA 1999, 96:9218-9223.

58. Portwich A, Garcia-Pichel F: A novel prokaryotic UVB photoreceptor in the cyanobacterium Chlorogloeopsis PCC 6912. Photochem Photobiol 2000, 71:493-498.

59. Cooper S: Checkpoints and restriction points in bacteria and eukaryotic cells. Bioessays 2006, 28:1035-1039.

60. Rudolph CJ, Upton AL, Lloyd RG: Replication fork stalling and cell cycle arrest in UV-irradiated Escherichia coli. Genes Dev 2007, 21:668-681.

61. Theisen PW, Grimwade JE, Leonard AC, Bogan JA, Helmstetter CE: Correlation of gene-transcription with the time of initiation of chromosome-replication in Escherichia coli. Mol Microbiol 1993, 10:575-584.

62. Hottes AK, Shapiro L, McAdams HH: DnaA coordinates replication initiation and cell cycle transcription in Caulobacter crescentus. Mol Microbiol 2005, 58:1340-1353.
63. Lobner-Olesen A, Skarstad K, Hansen FG, Vonmeyenburg K, Boye E: The DnaA protein determines the initiation mass of Escherichia coli K-12. Cell 1989, 57:881-889.

64. Boye $\mathrm{E}$, Lobner-Olesen A, Skarstad K: Limiting DNA replication to once and only once. EMBO Rep 2000, 1:479-483.

65. Sekimizu K, Bramhill D, Kornberg A: ATP activates dnaA protein in initiating replication of plasmids bearing the origin of the $E$. coli chromosome. Cell 1987, 50:259-265.

66. Marbouty M, Saguez C, Cassier-Chauvat C, Chauvat F: ZipN, an FtsA-like orchestrator of divisome assembly in the model cyanobacterium Synechocystis PCC6803. Mol Microbiol 2009, 74:409-420.

67. Ng WO, Zentella R, Wang YS, Taylor JSA, Pakrasi HB: phrA, the major photoreactivating factor in the cyanobacterium Synechocystis sp. strain PCC6803 codes for a cyclobutane-pyrimidine-dimer-specific DNA photolyase. Arch Microbiol 2000, 173:412-417.

68. Osburne MS, Holmbeck BM, Frias-Lopez J, Steen R, Huang K, Kelly L, Coe A, Waraska K, Gagne A, Chisholm SW: UV hyper-resistance in Prochlorococcus MED4 results from a single base pair deletion just upstream of an operon encoding nudix hydrolase and photolyase. Environ Microbiol 2010.

69. Prochlorococcus portal. [http://proportal.mit.edu/].

70. Truglio JJ, Croteau DL, Van Houten B, Kisker C: Prokaryotic nucleotide excision repair: The UvrABC system. Chemical Rev 2006, 106:233-252.

71. Van Houten B, Croteau DL, Della-Vecchia MJ, Wang H, Kisker C: 'Closefitting sleeves': DNA damage recognition by the UvrABC nuclease system. Mutation Res 2005, 577:92-117.

72. Schofield MJ, Hsieh P: DNA mismatch repair: Molecular mechanisms and biological function. Ann Rev Microbiol 2003, 57:579-608.

73. Schlacher K, Pham P, Cox MM, Goodman MF: Roles of DNA polymerase V and RecA protein in SOS damage-induced mutation. Chem Rev 2006 106:406-419.

74. Shinagawa $H$, Iwasaki $H$, Kato $T$, Nakata A: RecA protein-dependent cleavage of UmuD protein and SOS mutagenesis. Proc Natl Acad Sci USA 1988, 85:1806-1810.

75. Tippin B, Pham P, Goodman MF: Error-prone replication for better or worse. Trends Microbiol 2004, 12:288-295.

76. West SC: Processing of recombination intermediates by the RuvABC proteins. Annu Rev Genet 1997, 31:213-244.

77. Mazon G, Lucena JM, Campoy S, de Henestrosa ARF, Candau P, Barbe J: LexA-binding sequences in Gram-positive and cyanobacteria are closely related. Mol Genet Genom 2004, 271:40-49.

78. Erill I, Campoy S, Barbe J: Aeons of distress: an evolutionary perspective on the bacterial SOS response. FEMS Microbiol Rev 2007, 31:637-656.

79. Courcelle J, Khodursky A, Peter B, Brown PO, Hanawalt PC: Comparative gene expression profiles following UV exposure in wild-type and SOSdeficient Escherichia coli. Genetics 2001, 158:41-64.

80. Slilaty SN, Little JW: Lysine-156 and serine-119 are required for LexA repressor cleavage - A possible mechanism. Proc Natl Acad Sci USA 1987 84:3987-3991.

81. Patterson-Fortin LM, Colvin KR, Owttrim GW: A LexA-related protein regulates redox-sensitive expression of the cyanobacterial RNA helicase, CrhR. Nucl Acids Res 2006, 34:3446-3454

82. Domain $F$, Houot $L$, Chauvat $F$, Cassier-Chauvat $C$ : Function and regulation of the cyanobacterial genes lexA, recA and ruvB: LexA is critical to the survival of cells facing inorganic carbon starvation. Mol Microbiol 2004, 53:65-80.

83. Kielbasa SM, Herzel H, Axmann IM: Regulatory elements of marine cyanobacteria. Genome Informatics Covent Garden: Imperial College PressMiyano S, DeLisi C, Holzhutter HG, Kanehisa M 2007, 18:1-11.

84. Fernandez de Henestrosa AR, Ogi T, Aoyagi S, Chafin D, Hayes J J Ohmori H, Woodgate R: Identification of additional genes belonging to the LexA regulon in Escherichia coli. Mol Microbiol 2000, 35:1560-1572.

85. Tsinoremas NF, Ishiura M, Kondo T, Anderson CR, Tanaka K, Takahashi H, Johnson $\mathrm{CH}$, Golden SS: A sigma factor that modifies the circadian expression of a subset of genes in cyanobacteria. EMBO J 1996, 15:2488-2495.

86. Sherratt DJ: Bacterial chromosome dynamics. Science 2003, 301:780-785.

87. Michel B: After 30 years of study, the bacterial SOS response still surprises us. PLOS Biol 2005, 3:1174-1176. 
88. Steglich C, Futschik M, Rector T, Steen R, Chisholm SW: Genome-wide analysis of light sensing in Prochlorococcus. J Bacteriol 2006, 188:7796-7806.

89. Latifi A, Ruiz M, Zhang CC: Oxidative stress in cyanobacteria. FEMS Microbiol Rev 2009, 33:258-278.

90. Rippka R, Coursin T, Hess W, Lichtlé C, Scanlan DJ, Palinska KA, Iteman I, Partensky F, Houmard J, Herdman M: Prochlorococcus marinus Chisholm et al. 1992 subsp. pastoris subsp. nov. strain PCC 9511, the first axenic chlorophyll $a_{2} / b_{2}$-containing cyanobacterium (Oxyphotobacteria). Int/ J Syst Evol Microbiol 2000, 50:1833-1847.

91. Bruyant F, Babin M, Sciandra A, Marie D, Genty B, Claustre H, Blanchot J, Bricaud A, Rippka R, Boulben S, et al: An axenic cyclostat of Prochlorococcus PCC 9511 with a simulator of natural light regimes. J Appl Phycol 2001, 13:135-142.

92. Jacquet S, Lennon JF, Vaulot D: Application of a compact automatic sea water sampler to high frequency picoplankton studies. Aquat Microb Ecol 1998, 14:309-314.

93. Marie D, Partensky F, Vaulot D, Brussaard C: Enumeration of phytoplankton, bacteria, and viruses in marine samples. Current Protocol Cytom 1999, 10:11.11.11-11.11.15.

94. Marie D, Simon N, Guillou L, Partensky F, Vaulot D: DNA/RNA analysis of phytoplankton by flow cytometry. Curr Protocol Cytom 2000, 11:11.11.11-11.12.18.

95. Vaulot D: CYTOPC: Processing software for flow cytometric data. Signal Noise 1989, 2

96. User Bulletin \#2 - ABI PRISM 7700 Sequence Detection System (Applied Biosystems). [http://www3.appliedbiosystems.com/cms/groups/ mcb_support/documents/generaldocuments/cms_040980.pdf].

97. NimbleGen Arrays User's Guide - Gene Expression Analysis, version 3.0. [http://www.nimblegen.com/products/lit/expression_userguide_v5p0.pdf].

98. NimbleScan User's Guide, version 2.6. [http://www.nimblegen.com/ products/lit/NimbleScan_v2p5_UsersGuide.pdf].

99. R_Development_Core_Team: $\mathrm{R}:$ A language and environment for statistical computing. Computing RFfS. Vienna, Austria 2009 [http://www.Rproject.org].

100. Nakao M, Okamoto S, Kohara M, Fujishiro T, Fujisawa T, Sato S, Tabata S, Kaneko T, Nakamura Y: CyanoBase: the cyanobacteria genome database update 2010. Nucl Acids Res 2009, 38:D379-D338.

101. Bolstad BM, Collin F, Simpson KM, Irizarry RA, Speed TP: Experimental design and low-level analysis of microarray data. Int Rev Neurobio/ 2004 60:25-58.

102. Gentleman RC, Carey VJ, Bates DM, Bolstad B, Dettling M, Dudoit S, Ellis B, Gautier L, Ge Y, Gentry J, et al: Bioconductor: open software development for computational biology and bioinformatics. Genome Biol 2004, 5:R80.

103. Smyth GK, Speed T: Normalization of cDNA microarray data. Methods 2003, 31:265-273.

104. Smyth GK: Linear models and empirical bayes methods for assessing differential expression in microarray experiments. Stat Appl Genet Mol Biol 2004, 3, Art. 3.

105. Churchill GA: Using ANOVA to analyze microarray data. Biotechniques 2004, 37:173-177.

106. Kerr MK, Martin M, Churchill GA: Analysis of variance for gene expression microarray data. J Comput Biol 2000, 7:819-837.

107. Thissen D, Steinberg L, Kuang D: Quick and easy implementation of the Benjamini-Hochberg procedure for controlling the false positive rate in multiple comparisons. J Educ Behav Stat 2002, 27:77-83.

108. Eisen MB, Spellman PT, Brown PO, Botstein D: Cluster analysis and display of genome-wide expression patterns. Proc Natl Acad Sci USA 1998, 95:14863-14868.

doi:10.1186/1471-2180-10-204

Cite this article as: Kolowrat et al:: Ultraviolet stress delays chromosome replication in light/dark synchronized cells of the marine cyanobacterium Prochlorococcus marinus PCC9511. BMC Microbiology 2010 10:204.

\section{Submit your next manuscript to BioMed Central and take full advantage of:}

- Convenient online submission

- Thorough peer review

- No space constraints or color figure charges

- Immediate publication on acceptance

- Inclusion in PubMed, CAS, Scopus and Google Scholar

- Research which is freely available for redistribution

Submit your manuscript at www.biomedcentral.com/submit 